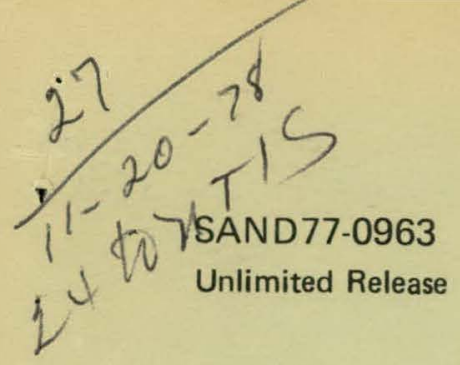

\title{
Preliminary Design of the Cooling System for a Gas-Cooled, High-Fluence Fast Pulsed Reactor (HFFPR)
}

Henry C. Monteith

Prepared by Sandia Laboratories, Albuquerque, New Mexico 87185

and Livermore, California 94550 for the United States Department

of Energy under Contract AT $(29-1)-789$

Printed October 1978 


\section{DISCLAIMER}

This report was prepared as an account of work sponsored by an agency of the United States Government. Neither the United States Government nor any agency Thereof, nor any of their employees, makes any warranty, express or implied, or assumes any legal liability or responsibility for the accuracy, completeness, or usefulness of any information, apparatus, product, or process disclosed, or represents that its use would not infringe privately owned rights. Reference herein to any specific commercial product, process, or service by trade name, trademark, manufacturer, or otherwise does not necessarily constitute or imply its endorsement, recommendation, or favoring by the United States Government or any agency thereof. The views and opinions of authors expressed herein do not necessarily state or reflect those of the United States Government or any agency thereof. 


\section{DISCLAIMER}

Portions of this document may be illegible in electronic image products. Images are produced from the best available original document. 
Issued by Sandia Laboratories, operated for the United States Department of Energy by Sandia Corporation.

\section{NOTICE}

This report was prepared as an account of work sponsored by the United States Government. Neither the United States nor the Department of Energy, nor any of their employees, nor any of their contractors, subcontractors, or their employees, makes any warranty, express or implied, or assumes any legal liability or responsibility for the accuracy, completeness or usefulness of any information, apparatus, product or process disclosed, or represents that its use would not infringe privately owned rights.

Printed in the United States of America

Available from

National Technical Information Service

U. S. Department of Commerce

5285 Port Royal Road

Springfield, VA 22161

Price: Printed Copy $\$ 5.25$; Microfiche $\$ 3.00$ 


\section{PAGES 1 to 2 WERE INTENTIONALLY LEFT BLANK}


SAND77-0963

Unlimited Release

Printed October 1978 PRELIMINARY DESIGN OF THE COOLING SYSTEM FOR A
GAS-COOLED, HIGH-FLUENCE FAST PULSED REACTOR (HFFPR)

$\because$

Henry C. Monteith

Reactor Safety Studies Division 4411

Sandia Laboratories

Albuquerque, New Mexico 87185

\section{ABSTRACT}

The High-Fluence Fast Pulsed Reactor (HFFPR) is a research reactor concept currently being evaluated as a source for weapon effects experimentation and advanced reactor safety experiments. One of the designs under consideration is a gas-cooled design for testing large-scale weapon hardware or large bundles of full-length, fast reactor fuel pins. This report describes a conceptual cooling system design for such a reactor. The primary coolant wnuld be helium and the secondary coolant would be water. The size of the helium-to-water heat exchanger and the water-to-water heat exchanger will be on the order of 0.9 metre $(3$ feet) in diameter and 3 metres ( 10 feet) in length. Analysis indicates that the entire cooling system will easily fit into the existing Sandia Engineering Reactor Facility (SERF) building. 'The alloy Incoloy $800 \mathrm{H}$ appears to be the best candidate for the tube material in the heliuil-to-water heat exchanger. Type 316 stainless steel has been recommended for the shell of this heat exchanger. Estimates place the cost of the helillm-t.n-water heat. exchanger at approximately $\$ 100,000$, the water-to-water heat exchanger at approximately $\$ 25,000$, and the helium pump at approximately $\$ 450,000$. The overall cost of the cooling system will approach $\$ 2$ million.

This report was prepered 
In the process of obtaining information for this report, the author consulted with many scientists from Sandia lyaboratorifos and the Los Alamos. Scientific Laboratory (LASL).

The author gives special thanks to Jeffrey s. Philbin, John A; Anderson, Earl E. Rush, R. K. Thomas, Harold C. Walling, J. P. Apbin, and Charles H. Maak, all of Sandia Laboratories. Special thanks are also due to Fred Sohilling, Robert Warner, and Tom Merson of IASL. Finally, it is impossible to express adequate appreciation for the expert work provided by the secretarial staff of sandia Laboratories. 


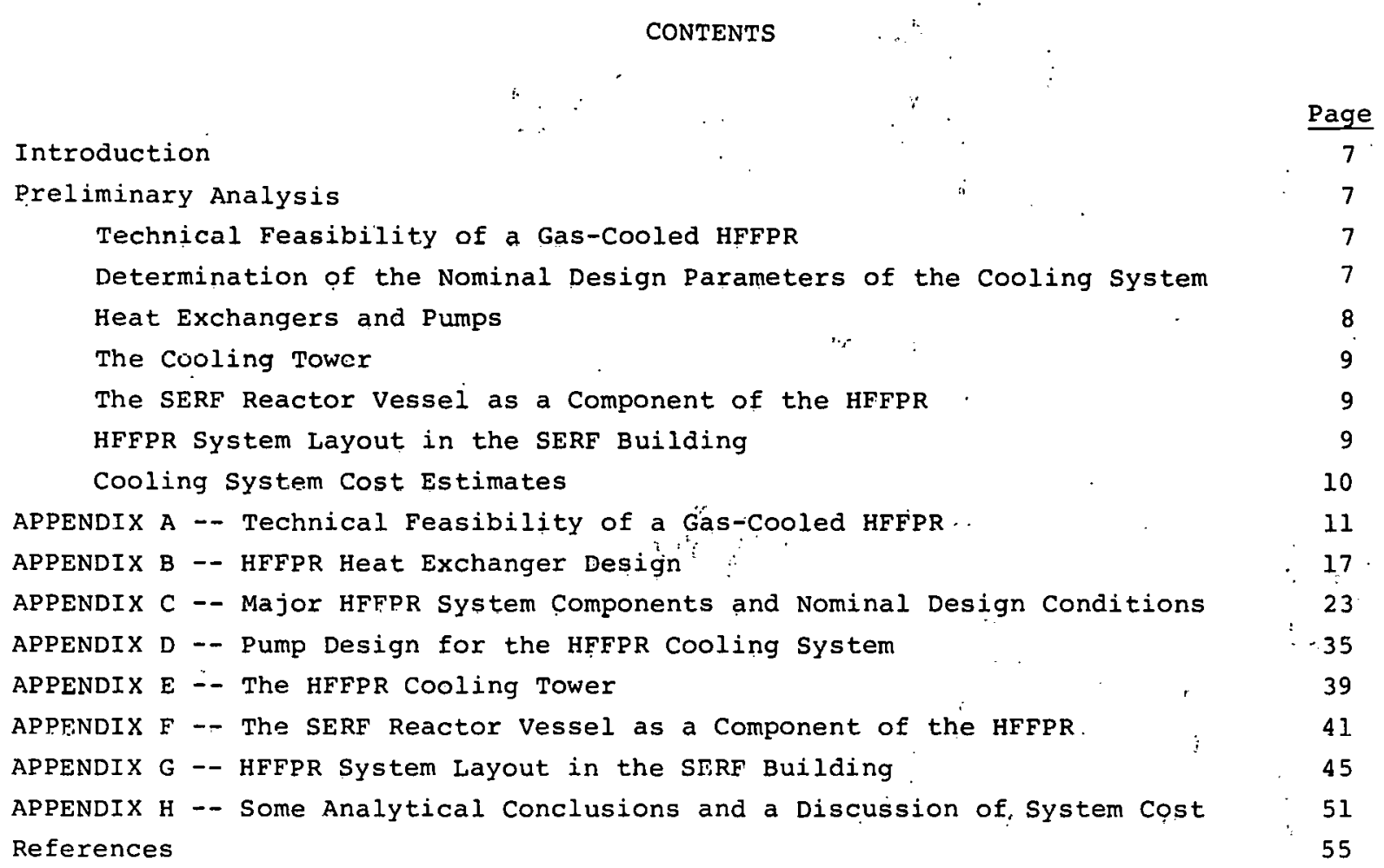

\section{ILLUSTRATIONS}

\begin{tabular}{clr} 
Figure & & $\cdot$ \\
\hline 1 & Cooling System Block Diagram & 8 \\
A-1 & Heat Disposal Circuit for the Dragon Reactor & 14 \\
B-1 & Cooling System Block Diagram for HFFPR & 17 \\
B-2 & Several Arrangements of Tubes in Bundles & 20 \\
C-1 & U-Tube Heat Exchanger & 25 \\
C-2 & Triangular Lattice & 29 \\
C-3 & Westinghouse Cooling System with Reboiler & 32 \\
C-4 & HFFPR System Components and Nominal Design Conditions & 33 \\
D-1 & Coolant Loop Blower & 35 \\
D-2 & Dimensions of Helium Pump & 36 \\
D-3 & Cross-Sectional Dimensions of the Helium Pump \\
D-4 & Water Pump Configuration & 37 \\
E-1 & Cooling Tower Configuration & 38 \\
F-1 & Constraints on SERF Reactor Vessel \\
G-1 & Eandia Engineering Reactor Facility (SERF) \\
G-2 & Ground Floor Plan & 40 \\
G-3 & Basement Flon Plan
\end{tabular}




\section{ILLUSTRATIONS (Continued)}

G-4 Mezzanine Floor Plan

PLBLES

\section{Table}

I Estimated Costs for the HFFPR Cooling syṣtem . . . 10

A-I Main Dessign Parameters of the Peach Bottom HTTGR 1.2

A-II Dragon Reactur Experiment: General Data 13

A-III UHTREX Design Parameters $\quad$. . . . . 15

C-I Helium Heat Exchanger Parameters. . . 30

C-IH Water Heat Exchanger Parameters . . . 30

C-III Pressures and Mass Flow Rates 31

H-I Estimated Prices of Major Components . . . . 53 
PRELIMINARY DESIGN 'OF THE COOLING SYSTEM FOR A GAS-COOLED, HIGH-FLUENCE FAST PULSED REACTOR (HFFPR)

\section{Introduction}

As a part of the Sandia Laboratories continuing effort toward reactor design and development in support of Laboratories programs, a conceptual design has been developed for a High-Fluence Fast Pulsed Reactor (HFFPR).

The work described in this report was undertaken for the following reasons:

1. To perform a preliminary linear analysis and to estimate the nominal design parameters for the major system components necessary to the construction of a cooling system for the HFFPR,

2. To estimate the space which will be required to house the components of. the HFFPR,

3. To determine the approximate cost of the major cooling system components in 1977 dollars, and

4. To evaluate the practicality of placing the HFFPR system in the sandia Engineering Reactor Facility (SERF) building.

\section{Preliminary Analysis}

The preliminary analysis and associated research performed on the HFFPR produced some interesting results. These results are briefly discussed in the subsections which follow.

\section{Technical Feasibility of a Gas-Cuoled HFFFR}

The technology of high-temperature, gas-cooled systems has been adequately demonstrated in the following instances:

1. The Peach Bottom prototype HTGR power plant,

2. The Dragon Reactor experiment, and

3. The Los Alamos Ultra High Temperature Reactor Experiment (UHTREX). The characteristics of these reactors and their relationship to the design of the HFFPR are discussed in Appendix A.

Determination of the Nominal Design Parameters of the Cooling system

The basic cooling system design consists of the following two heat exchangers:

1. Exchanger 1 in which heat is transferred from the primary helium loop to the intermediate water loop, and 
2. Exchanger 2 in which heat is transferred from the intermediate water loop to the cooling tower.

Since the possibility exists that Exchanger 1 could become contaminated, Exchanger 2 serves to isolate the cooling tower from Exchanger 1 , A linear mathematical analysis of the cooling system, as shown in Figure 1 , is contained in Appendix B.
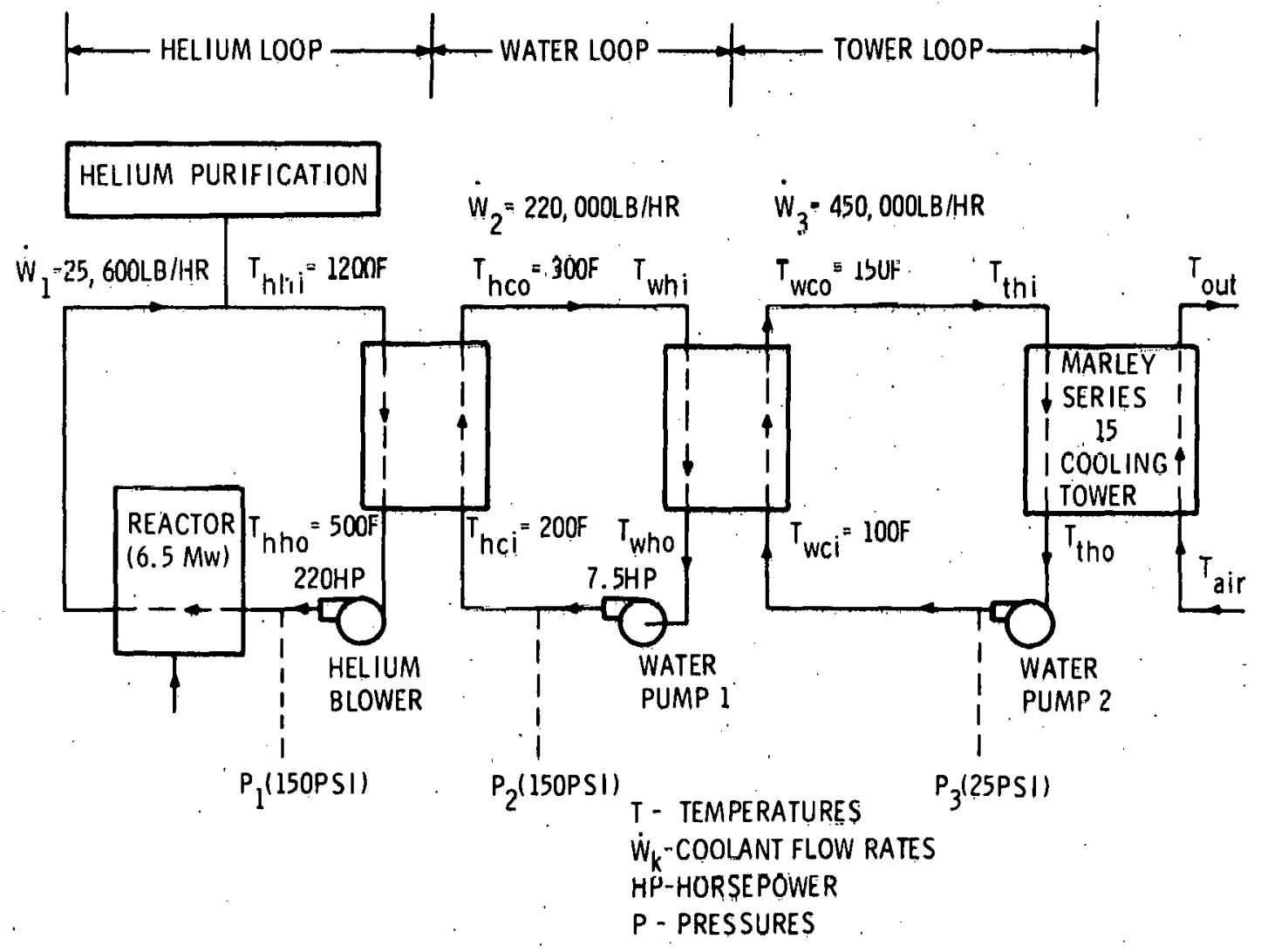

Figure 1. Cooling System Block Diagram

\section{Heat Exchangers and Pumps}

A thorough analysis of the heat exchangers is contained in Appendix $c$. Because of its simplicity and ability to withstand thermal stresseș, a helium-towater heal exchanger of the U-tube type was used. The structural design guide for the helium heat exchanger is code Case 1592 (Class 1 components in elevated temperature service) found in section III of the ASME Boiler and Pressure vesse] Code.

An analysis of the water heat exchanger is also contained in Appendix $C$. The mass flow rates through both heat exchangers are indicated in Figure 1 . The results of the linear analysis, as well as the results of analyses submitted by different manufacturers, indicate that the size of both heat exchangers will be on the order of 0,9 metre ( $3 \mathrm{feet}$ ) in diameter and 3 metres $(10$ feet) in length. 
One of the manufacturers, Mechanical Technology Incorporated (MTI), has considerable experience in the manufacture of helium pumps. MTI manufactured the helium blowers for the UHTREX reactor and is currently designing similar blowers for Union Carbide and Oak Ridge National Laboratory (ORNL).

The circulator can easily handle $3.3 \mathrm{~kg} / \mathrm{s}(26,000 \mathrm{lb} / \mathrm{h})$ of helium at 150 psia and $315^{\circ} \mathrm{C}\left(600^{\circ} \mathrm{F}\right)$. with a head rise between $17 \mathrm{kPa}$ and $35 \mathrm{kPa}(2.5$ and 5 psi). Approximate power would be $82 \mathrm{~kW}(110 \mathrm{hp})$ at $17 \mathrm{kPa}(2.5 \mathrm{psi})$ head and $164 \mathrm{~kW}(220 \mathrm{hp})$ at $35 \mathrm{kPa}$ ( $5 \mathrm{psi}$ ) head. Water pump 1, which is located between the two heat exchangers, will operate at a speed of $1750 \mathrm{rpm}$ and will have a power of about $5.6 \mathrm{~kW}(7.5 \mathrm{hp})$. Water pump 2, which serves the cooling tower, will have a power of about $37 \mathrm{~kW}(50 \mathrm{hp})$ and run at $1750 \mathrm{rpm}$. Further details on the pumps are given in Appendix $D$.

\section{The Cooling Tower}

The cooling tower is a Marley series 15 forced draught tower. It is able to handle $56.7 \mathrm{~kg} / \mathrm{s}(450,000 \mathrm{lb} / \mathrm{h})$ of water and drop the water temperature from $65^{\circ} \mathrm{C}$ to $38^{\circ} \mathrm{C}\left(150^{\circ} \mathrm{F}\right.$ to $\left.100^{\circ} \mathrm{F}\right)$. It will cover an area 6.1 by 4.9 metres ( 20 by 16 feet) and will stand 5.2 metres ( 17 feet) high. The fan will be powered by a $15 \mathrm{~kW}(20 \mathrm{hp})$ motor. Appendix E presents a schematic of the cooling tower.

\section{The SERF Reactor Vessel as a Component of the HFFPR}

A preliminary survey of the SERF reactor vessel was made to determine if it might be used with the HFFPR. Analysis indicated that the design stresses of this vessel will be exceeded if it is subjected to temperatures on the order of $649^{\circ} \mathrm{C}$ $\left(1200^{\circ} \mathrm{F}\right)$.

The vessel is locked into strong concrete and very little room is allowed for expansion; consequently, it should not be subjected to a temperature higher than $177^{\circ} \mathrm{C}\left(350^{\circ} \mathrm{F}\right)$. If a design scheme can be devised in which the upper vessel is retained and is not subjected to temperatures greater than $177^{\circ} \mathrm{C}$ $\left(350^{\circ} \mathrm{F}\right)$, then the new lower vessel should be designed to avoid transmitting high stresses to the upper vessel.

It may be possible to devise a scheme by which the existing water cooling system for the vessel can be modified to keep its temperature below $177^{\circ} \mathrm{C}$ $\left(350^{\circ} \mathrm{F}\right)$. If this is possible, then the vessel may prove usable for the HFFPR. Further details are provided in Appendix F.

\section{HFFPR System Layout in the SERF Building}

The suggested location for the helium-to-water exchanger is the beam room which is situated north of the irradiation cell and on the same level. In this location, it will be adequately shielded and at the same time it will be in close proximity to the reactor for ease of operation. The secondary heat exchanger may be placed in the pump house along with the two water pumps. (The pump house is a 
new addition to the SERF building.) Finally; the helium purification system should be constructed as a modular unit and placed in Lock No. 1 after it has been provided with a gas-tight liner. Lock No. I is located west of the irradiation cell and on the same level. Further details may be obtained from Appendix G.

\section{Cooling System Cost Estimates}

Estimated costs for all the major components in the cooling system are summarized in Table $I$.

TABLE I

Estimated Costs for the HFFPR Cooling System

Component

Holium heat exclianyes.

Water heat exchanger

Helium pump .

Helium pump controller.

water pump 1

Water pump 2

Helium Purification

Total
Cost

$\$ 100,000^{\circ}$

$\$ 25,000$

$\$ 450,000$

$\$ 75,000$

$\$ 1,700$

$\$ 3,000$

$\$ 250,000$

$\$ 904,700$

If duplicate pumps are to be utilized in case of pump failure, an additional $\$ 455,000$ must be added to the calculated total. If an extra $\$ 5 n \cap, n \cap n$ for tho purchase of other equipment is also added in, the entire cooling system could cost as much as $\$ 2$ million for hardware alone. 


\section{APPENDIX A}

Technical Feasibility of a Gas-Cooled HFFPR

The technology of the high-temperature, gas-cooled reactor is sufficiently advanced to make it a viable option for the proposed HFFPR. Information from the following nuclear reactor demonstration projects suggested design criteria for the HFFPR:

1. The Peach Bottom prototype HTGR power plant,

2. The Dragon Reactor experiment,

3. The Los Alamos UHTREX, and

4. The General Atomic gas-cooled breeder reactor design.

The main design parameters for the Peach Bottom HTGR are listed in Table
A-I. ${ }^{-3}$ The heat exchangers for this reactor had helium in the primary circuit and water in the secondary circuit. Helium was allowed to flow around the outside of the heat exchanger tubes while water flowed inside the tubes. The same type of heat exchanger concept is suggested for the gas-cooled HFFPR. High temperatures, helium leakage, and limited space impose strict design criteria upon the heat exchangers; however, these criteria were adequately met during the design of the Peach Bottom HTGR. Even though this reactor generated $115 \mathrm{MW}(t)$, the steam generators were only 8.6 metres (28 feet, 4 inches) long and 2.3 metres (7.5 feet) in diameter. Since the proposed HFFPR will generate only $6.5 \mathrm{MW}(t)$, it is reasonable to assume that the necessary heat exchangers can be accommodated in the SERF structure since the size of the heat exchanger is proportional to the heat energy it must transfer. Thermal stresses and material demands are also expected to be less than those encountered in the Peach Bottom HTGR; rnnsequently, the cooling system components might be more readily available and less expensive.

Another reactor design which had some characteristics in common with the proposed HFFPR was the Dragon Reactor experiment. ${ }^{4-6}$ Some characteristics of this reactor are presented in Table A-II. The helium temperatures for this reactor are very close to those temperatures proposed for the HFFPR. The heat exchangers of this reactor were designed to a high standard of leak tightness in nrier to prevent the escape of helium which could also carry some decay products.

The heat removal system for the Dragon Reactor has many characteristics in common with the cooling system proposed for the HFFPR. In the Dragon reactor, two heat exchangers were used in each coolant loop and the generated heat was dissipated through a cooling tower. In the HFFPR, a single loop with two heat 
TABLE A-I

Main Design Parameters of the Peach Bottom HTGR

Reactor heat output

Plant net power

Core active dimensions

Fuel elements

Core fuel initial loading

Heat flux

Power density, kW/Liter

specific power

Average conversion ratio

Excess reactivity

Control rods

Coolant

coolant conditions

Circulators

Steam-cycle conditions

Steam-cycle equipment

Plant efficiency
$115.3 \mathrm{MW}(t)$

$40 \mathrm{MW}(\mathrm{e})$

2.8 metres $(9.16$ feet) in diameter and 2.3 metres $(7.5$ feet) high

804 (U. Thir fueled, graphite clad; $\left(U+T l_{i}\right) 1$ atom percent, 20 mass percent in compacts

$200 \mathrm{~kg}_{\mathrm{m}} \mathrm{u}^{235}, 13 \mathrm{~kg}_{\mathrm{m}} \mathrm{u}^{238}$,

$1897 \mathrm{~kg}_{\mathrm{m}} \mathrm{Th}$

$25 \cdot \mathrm{kW} / \mathrm{m}^{2}\left(8000 \mathrm{Btu} / \mathrm{ft} \mathrm{t}^{2} \cdot \mathrm{h}\right)$ average, $322 \mathrm{~kW} / \mathrm{m}^{2}\left(102,000 \mathrm{Btu} / \mathrm{ft}^{2} \cdot \mathrm{h}\right)$ peak

8.24

$580 \mathrm{~kW}(\mathrm{t}) / \mathrm{kg}_{\mathrm{m}} \mathrm{u}^{235}$

0.50

19 percent cold clean, 8 percent hot. clean, 5 percent hot poisoned

$36 \mathrm{~B}_{4} \mathrm{C}$ rods

$\mathrm{He}$

$334^{\circ} \mathrm{C}\left(634^{\circ} \mathrm{F}\right)$ reacţor inlet. $734^{\circ} \mathrm{C}\left(1354^{\circ} \mathrm{F}\right)$ outlet, $335 \mathrm{psig}$ vessel pressure, $69 \mathrm{kPa}$ ( 10 psi) rise in circulators. $55.4 \mathrm{~kg} / \mathrm{s}$ ( 439,600 pound-mass $/ \mathrm{h})$ total flow rate, $0.12 \mathrm{~kg} / \mathrm{c}$ (I000 peuind-nass/li) purge rate.

Two $16 \mathrm{~m}^{3} / \mathrm{s}\left(33,800 \mathrm{ft}^{3} / \mathrm{min}\right)$ horizontal single-stage centrifugal, 1.9 MW (2500-hp) motors each

$538^{\circ} \mathrm{C}\left(1000^{\circ} \mathrm{F}\right), 1450 \mathrm{psig}$ at turbine throtele $218^{\circ} C^{\circ}\left(425^{\circ} \mathrm{F}\right)$ economizer inlet

Two forced recirculation steam generators, one tandem-compound, double-flow 46-MW(e) gross turbine, one single-pass divided box condenser, three horizontal U-tube feedwater heaters

39.9 percent gross, 34.7 percent net 
TABLE A-II

Dragon Reactor Experiment: General Data

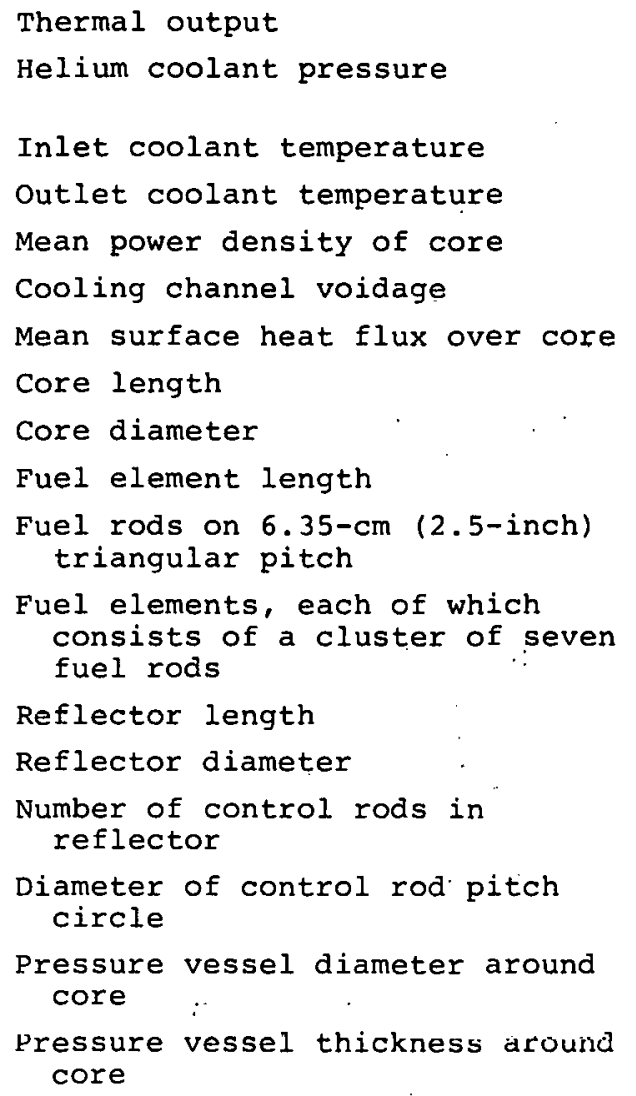

$20 \mathrm{MW}$

$2.03 \mathrm{MPa}(20 \mathrm{~atm}$ or 294

$350^{\circ} \mathrm{C}\left(662^{\circ} \mathrm{F}\right)$

$750^{\circ} \mathrm{C}\left(1382^{\circ} \mathrm{F}\right)$

$14 \mathrm{MW} / \mathrm{m}^{3}$

13 percent

$24 \mathrm{~W} / \mathrm{cm}^{2}$

1.6 metres ( 5 feet, 3 inches)

1.07 metres ( 3 feet, 6 inches)

2.54 metres ( 8 feet, 4 inches)

259

37

2.45 metres ( 8 feet, 0.5 inch)

2.89 metres $(9$ feet, 6 inch

24

1.23 metres ( 4 feet, 0.5 inch)

3.5 metres ( 11 feet, 6 inches)

$5 \mathrm{~cm}$ (2 inches)

exchangers is planned. The Dragon reactor cooling circuit is illustrated in Figure A-1. In this circuit, each primary heat exchanger transfers its heat to a secinlary eireuit loop of the forood circulation hoiling type. Water is partially evaporated in the primary heat exchangers and then the steam/water mixture is carried to the secondary heat exchangers where it is condensed and recirculated by rotor pumps. Natural circulation is used to transfer shutdown heat.

The UHTREX was built by LASL in order to advance the technology of gas-cooled reactors. ${ }^{7}$ A helium-cooled gas reactor was designed to operate at very high temperatures. Some of the design characteristics of this reactor are given in Table A-III. In this reactor, helium, which was the only coolant utilized, was passed through the cooling tower. A study of this system gives valuable insight into design methods for the handling of high temperatures, helium purification, and helium management. 


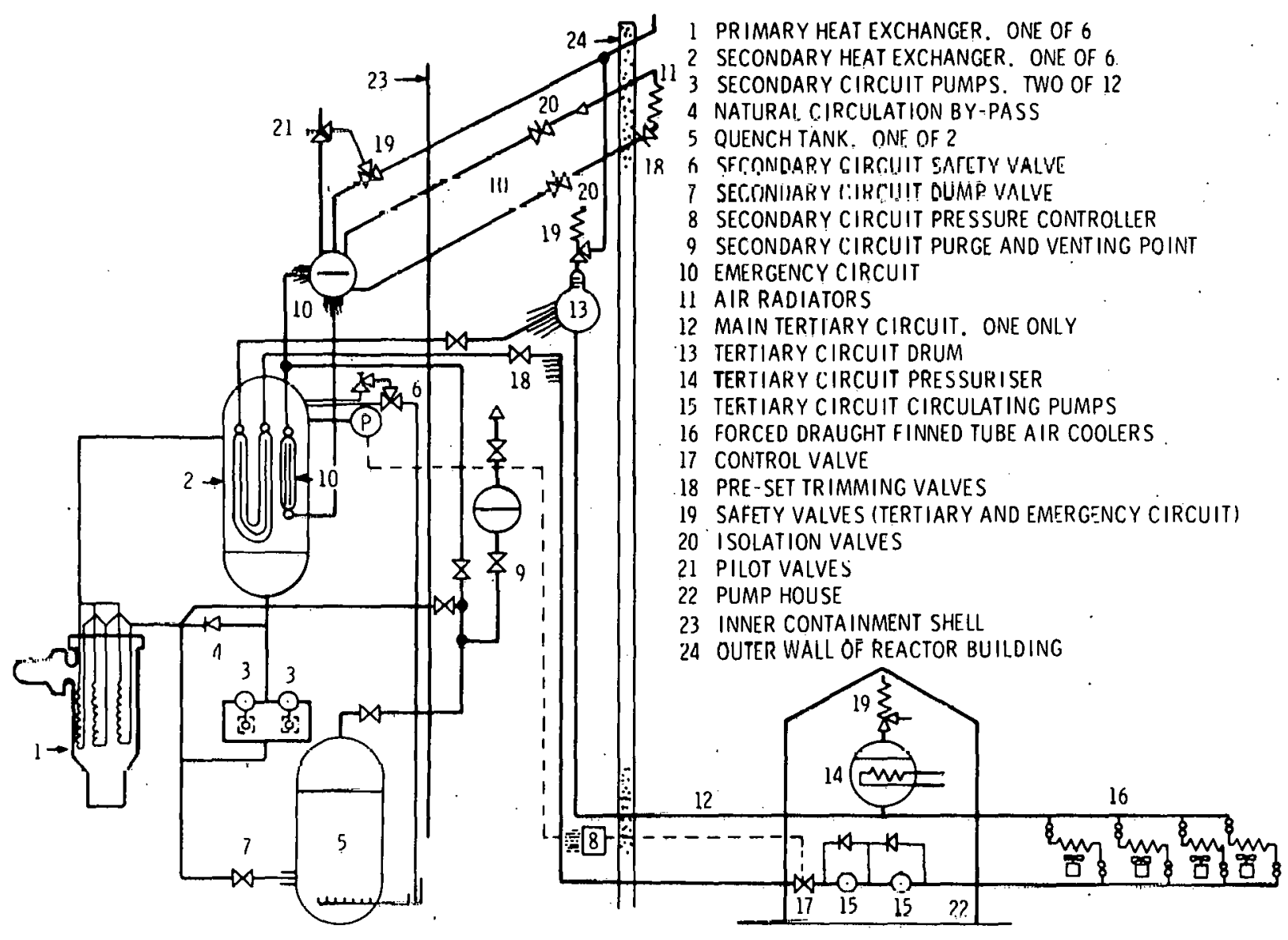

Figure $A-1$. Heat Disposal Circuit for the Dragon Reactor 
TABLE A-III

UHTREX Design Parameters

\author{
Nominal reactor power \\ Coolant mass flow rate \\ Coolant pressure \\ Outlet temperature \\ Inlet temperature \\ Number of assemblies \\ critical mass \\ Core loading at design power \\ Average specific power in fuel \\ Average power density in core \\ Burnup
}

\author{
3 MW $(t)$ \\ $1.29 \mathrm{~kg} / \mathrm{s}(10,250 \mathrm{lb} / \mathrm{h})$ \\ $3.26 \mathrm{MPa}$ (473.5 psi) \\ $1316^{\circ} \mathrm{C}\left(2400^{\circ} \mathrm{F}\right)$ \\ $871^{\circ} \mathrm{C}\left(1600^{\circ} \mathrm{F}\right)$ \\ 312 \\ $5.68 \mathrm{~kg}, 93.6$ percent \\ enriched uranium \\ $11.0 \mathrm{~kg}, 93.6$ percent \\ enriched uranium \\ $270 \mathrm{~kW} / \mathrm{kg}$ \\ $1.4 \mathrm{~kW} / 1$ iter \\ 10 percent to 50 percent
}

The design criteria which have been presented for the gas-cooled fast breeder reactor also have useful implications for the HFFPR. This demonstration facility was planned to operate at $330 \mathrm{MW}(e) .8$ The fuel rods consist of annular (Pu-U) $\mathrm{O}_{2}$ pellets within a type 316 stainless steel cladding. The cladding, which is approximately $0.5 \mathrm{~mm}(20 \mathrm{mils})$ thick, is designed to handle a maximum temperature of $700^{\circ} \mathrm{C}\left(1292^{\circ} \mathrm{F}\right)$ at midthickness of the fuel cladding (including hot-spot factors). The design of the gas-cooled fast breeder reactor indicated that type 316 stainless steel is a feasible choice for the cladding in the HFFPR as well as in the heat exchangers. 9

$\Lambda 1000$ MW(e) version of the gas-cooled fast breeder reactor has also been planned. 10 It is to have a helium pressure of about $8.6 \mathrm{MPa}$ ( $1250 \mathrm{psi}$ ), a reactor inlet temperature of around $290^{\circ} \mathrm{C}\left(554^{\circ} \mathrm{F}\right)$, and a hot spot midclad temperature of $760^{\circ} \mathrm{C}\left(1400^{\circ} \mathrm{F}\right)$.

All of the design concepts which will be necessary for the HFFPR have been tested in the above projects. 


\section{APPENDIX B}

HFFPR Heat Exchanger Design

The basic block diagram for the cooling system which is being proposed for the HFFPR is illustrated in Figure B-1. The heat exchangers are fundamental. to the cooling system and very careful attention should be given to their design. Indeed, the proper design of the heat exchangers is extremely important to reactor operation and safety.
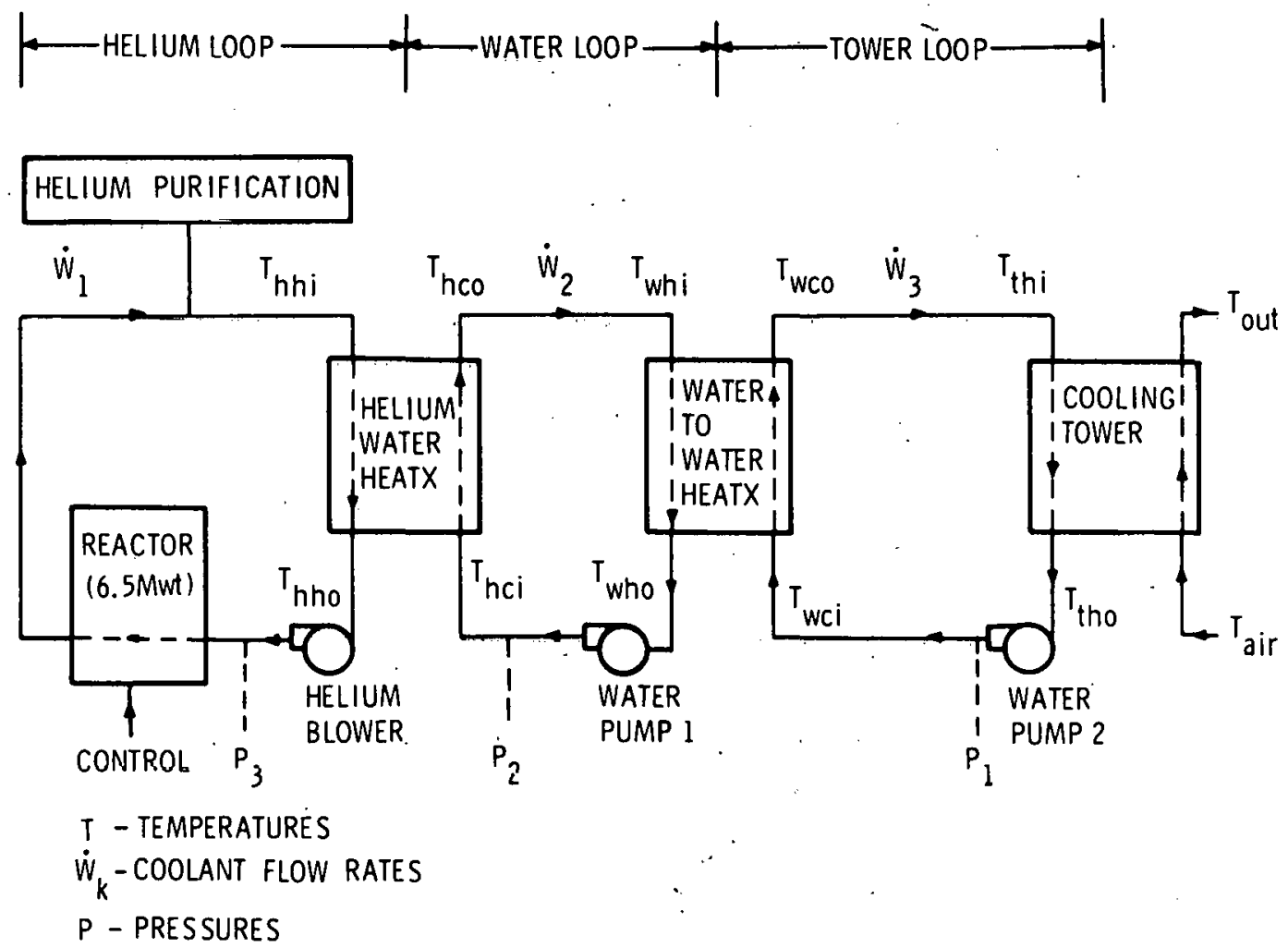

Figure B-1. Cooling syetem Block Diagram for HFF'PR

The design of a heat exchanger.is largely constrained by the temperatures at which it must operate, the amount of space available for mounting it, and the quantity of pressure it is allowed to drop. Figure $\mathrm{H}-1$ shows that for a given design power level of operation and a specified outlet temperature, the volume of the heat exchanger is influenced by the temperature drop across its primary.' The size of the heat exchanger will also decrease as the pressure it is allowed to drop increases. 11 
The integral and peripheral components of a high-temperature, gas-coolcd reactor must be designed to a very high level of reliability. This makes it essential that materials for these components be carefully selected.

The choice of the materials to be used in the heat exchangers is dictated by the following considerations:

1. Strong mechanical properties and metallurgical stability at operating temperature,

2. Corrosion resistance against primary and secondary media under normal as well as abnormal operating conditions,

3. Ease of fabrication, e.g., in welding and bending,

4. Conformity with the necessary codes, such as the ASME and TEMA codes,

5. Practical operating experienco,

6. Availability of materials, and

7. Cost of materials.

Fatigue strength is a key mechanical property of the material in the heat exchanger tubes because the tubes are subjected to thermal stresses associated with the radial temperature gradient through the tube walls. Therefore, it is necessary to consider the creep strength, yield strength, ultimate tensile strength, and fracture toughness of the tube material.

Some of the alloys which have been considered as possible candidates for the tubing material in the primary helium-to-water heat exchanger are Incoloy $800 \mathrm{H}$, Incoloy 802, Inconel 601, Inconel 617, Hastelloy 5, Hastelloy $x$, and Hastelloy c. Out of all these possibilities, Incoloy $800 \mathrm{H}$ is felt to he the bcot choice fur the heat exchanyer tubing material due to the following considerations: 12

1. It has very high creep strength at $704^{\circ} \mathrm{C}\left(1300^{\circ} \mathrm{F}\right)$,

2. It has a low alıminum sontont (this is lestrable because aluminum can contribute to helium reactor coolant corrosion).

3. It has excellent thermal stability,

4. It is free from cobalt and tantalum which can cause potential radioactivity problems,

5. It is readily available,

6. It has good fabricability,

7. It has the lowest cost of the candidate alloys, i.e., approximately $\$ 164$ per metre ( $\$ 50$ per foot), and

8. It has been certified for use with gas-cooled reactors and approved under the ASME Boiler and Pressure Vessel Code.

It is recommended that the shell of the heat exchanger be an all-welded pressure boundary of corrosion-resistant material such as stabilized stainless steel. This shell should he made extra thick as a precaution against helium leakage. Calculations indicate that the helium-to-water heat exchanger will be on the order of 0.9 metres ( 3 feet) in diameter and 3 metres (10 feet) in length. The shell will have to support the gas pressure which is assumed to be $1.03 \mathrm{MPa}$ 
(150 psi). It is suggested that the certified material (type 316 steel) be used as the shell material.

The thickness of the shell will be estimated based on a life time of 100,000 operational hours. At a temperature of $704^{\circ} \mathrm{C}\left(1300^{\circ} \mathrm{F}\right)$, a hoop tension of 27.6 $\mathrm{MPa}$ (4000 psi) will cause a creep rate of 0.00001 percent per hour. The circumference of the heat exchanger shell will be 2.87 metres ( 9 feet, 5 inches). Thus, over an operating period of 100,000 hours, the circumference will expand by $29 \mathrm{~mm}$ ( 1.13 inches) which can be easily tolerated. The thickness of the shell can be estimated with the following formula: 13

$$
t=\frac{(D)(P)}{(2)(H)}
$$

where

$$
\begin{aligned}
& D=\text { inner diameter in inches } \\
& P=\text { pressure in psi } \\
& H=\text { hoop tension in psi }
\end{aligned}
$$

Inserting the above values gives a thickness of $17 \mathrm{~mm}(0.68$ inches). Thus, a thickness of $19 \mathrm{~mm}(0.75 \mathrm{inch})$ for the shell of the helium-to-water heat exchanger seems to be adequate.

If the water in the tubes of the primary helium-to-water heat exchanger is also pumped at a pressure of $1.03 \mathrm{MPa}$ (150 psi), there will be no pressure in the tube walls. However, it is desirable to have the walls thick enough to stand $1.03 \mathrm{MPa}$ ( $150 \mathrm{psi}$ ) in case coolant flow fails in either the shell or the tubes. It has been recommended that Incoloy alloy $800 \mathrm{H}$ be used as the tube material. At $704^{\circ} \mathrm{C}\left(1300^{\circ} \mathrm{F}\right)$, a hoop tension of $24.1 \mathrm{MPa}$ (3500 psi) will cause a creep rate of 0.00001 percent per hour. Thus, the thickness of the tube walls is found from Eq. (B-1) to be about $0.4 \mathrm{~mm}(0.016$ inches). A standard tube size with a 19-mm (0.75-inch) inner diameter and a 27-mm (1.05-inch) outer diameter is chosen. The thickness of this tube is much greater than is required to sustain 150 psia. It is believed that this tube size is also adequate to support the potential differential pressure loads and thermal loads due to axial and radial thermal gradients; however, a detailed analysis of the helium-to-water heat exchanger will be necessary in order to confirm this. The structural design guide for the helium heat exchanger will be Code Case 1592 (Class I Components in Elevated Temperature Service), Section III of the ASME Boiler and Pressure Vessel Code. This code specifies a maximum allowable stress in tension of 32 MPa (4600 psi) at $704^{\circ} \mathrm{C}\left(1300^{\circ} \mathrm{F}\right)$ which is well above that expected with a lube thiejncoo of $4 \mathrm{~mm}(0.15 \mathrm{inch})$.

Tube bundles may have several kinds of arrangements (see Figure B-2). 14 The outer surfaces of the tubes may be cleaned more readily when the tubes are arranged on a square pitch rather than a triangular pitch. on the other hand, 
the triangular-type lattice allows greater turbulence and heat transfer surface per unit volume. This reduces the diameter of the heat exchanger, but the pressure drop may also be increased across the heat exchanger. The greater the allowed pressure drop, the lower will be the cost of the heat exchanger.

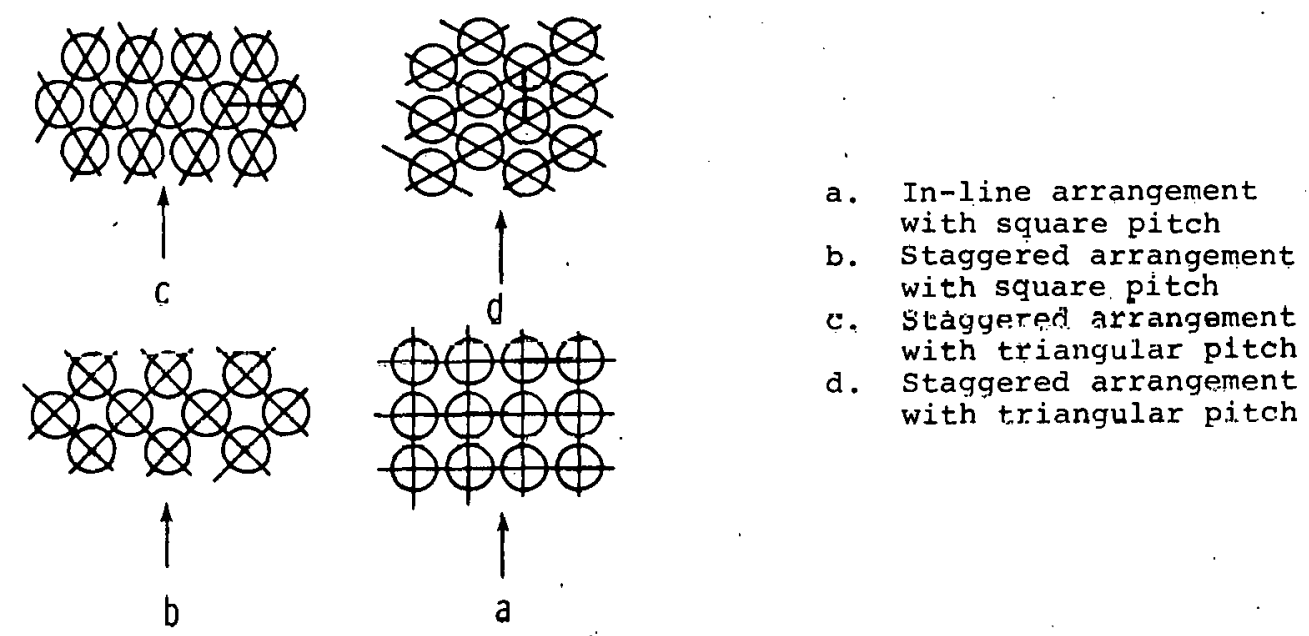

Figure B-2. Several Arrangements of Tubes in Bundies

It has been found that the nverall soot of a heat exchanger is minimum if the pumping power chargeable to the heat exchanger is in the range of 0.5 to 1 percent of the heat whirh is transforrcal 14 ff the pumping power is assumed to be 1 percent of the heat transferred, then for a $6.5 \mathrm{MW}(t)$ reactor, the pumping power will be $32.2 \mathrm{~kW} / \mathrm{h}(110, .000 \mathrm{Btu} / \mathrm{h}$ or $\sim 43.24 \mathrm{hp})$. A helium temperature of $260^{\circ} \mathrm{C}\left(500^{\circ} \mathrm{F}\right)$ is assumed to exist at the helium circulator, The reactor output temperature is assumed to be $649^{\circ} \mathrm{C}\left(1200^{\circ} \mathrm{F}\right)$ and the inlet temperature is taken to be $260^{\circ} \mathrm{C}\left(500^{\circ} \mathrm{F}\right)$. This gives an enthalpy drop of about $2.02 \mathrm{MJ} / \mathrm{kg}(869.4$ Btu/lb). The helium mass flow rate is then calculated to be about $3.1 .9 \mathrm{~kg} / \mathrm{s}$ $(25,305 \mathrm{lb} / \mathrm{h})$. The allowed drop in pressure across the heat exchanger is then estimated with the formula: 13

$$
\Delta P=\frac{(\rho)(w)}{\dot{m}_{n}}
$$

where

$$
\begin{aligned}
\rho & =\text { helium density in } 1 \mathrm{~b} / \mathrm{ft}^{3} \\
\Delta \mathrm{P} & =\text { pressure drop in } 1 \mathrm{~b} / \mathrm{ft}^{2} \\
\mathrm{~W} & =\text { pumping power in } \mathrm{ft}-\mathrm{lb} / \mathrm{s} \\
\dot{\mathrm{m}}_{\mathrm{n}} & =\text { helium mass flow rate in } 1 \mathrm{~b} / \mathrm{s}
\end{aligned}
$$


Inserting the proper values gives a pressure drop of about $13.8 \mathrm{kPa}$ (2 psi). Consultation with manufacturers indicates that if a triangular lattice is used, a pressure drop of $17.2 \mathrm{kPa}(2.5 \mathrm{psi})$ will bring about a good balance between all the above considerations.

The U-tube heat exchanger is simpler and cheaper than other types of heat exchangers and perhaps is also the best type of exchanger for this application. The U-tube structure eliminates failure due to severe thermal strains and it also allows for expansion. The U-tube structure is easier to seal than the floating head design; however, it is more difficult to clean the U-tubes by mechanical means. Adequate water and gas purification systems may make it unnecessary to clean the helium-to-water heat exchanger during its usable life. Such a system would also eliminate the contamination risk which might occur during cleaning of the primary helium heat exchanger.

Helium should be placed on the shell. side of the heat exchanger for the following reasons: 15

1. The most corrosive fluid should be inside the tubes,

2. Better heat transfer properties will result if the most inviscid fluid is on the shell side, and

3. It is desirable for the water to be at a pressure equal to or greater than the pressure of the helium and the fluid with the greatest pressure should be inside the tubes.

It has been found that a helium coolant pressure of less than $506 \mathrm{kPa}$ (5 atm) results in an excessively large heat exchanger which will require much pumping power. This would increase the cost of both the heat exchanger and the pump. It is felt that a coolant pressure of $1 \mathrm{MPa}$ (10 atm) is a good choice for the helium in the proposed HFFPR installation since related technology has been developed to handle much higher pressures.

The preceding considcratione indicate that the helium-to-water heat exchanger should have the following design characteristics:

1. A type 316 steel shell, $13 \mathrm{~mm}(0.5$ inch) thick,

2. Incoloy alloy $800 \mathrm{H}$ tubing material,

3. An imer diameter for the tubes of $19 \mathrm{~mm}(0.75 \mathrm{jinch})$,

4. An outer diameter for the tubes of $27 \mathrm{~mm}$ ( 1.05 inches),

5. Helium flow on the shell side,

6. Water flow in the tubes,

7. A triangular lattice for the tube bundle, and

8. A U-type heat exchanger. 
APPENDIX C

Major HFFPR System Components and Nominal Design Conditions

In this section, the entire cooling system will be considered as a unit and the interaction between the components will be estimated by means of simple linear analysis.

These calculations are not meant to be exact but are carried out only in order to provide a rough idea of what the nominal operating conditions might be in the system once it has been constructed. First, the basic core parameters are considered.

At the time this report was written, a complete analysis of the HFFPR reactor core had not been performed; consequently, it is necessary to make the following assumptions regarding the design parameters:

1. It is assumed that the helium will occupy 25 percent of the total core volume,

2. It is assumed that the core inlet temperature will be $260^{\circ} \mathrm{C}$ $\left(500^{\circ} \mathrm{F}\right)$,

3. It is assumed that the core outlet temperature will be $649^{\circ} \mathrm{C}$ $\left(1200^{\circ} \mathrm{F}\right)$, and

4. It is assumed that the core radius will be 0.8 metre $(2.5$ feet).

It is interesting to note that the Peach Bottom HTGR had an outlet temperature of $734^{\circ} \mathrm{C}\left(1354^{\circ} \mathrm{F}\right)$ and an inlet temperature of $334^{\circ} \mathrm{C}\left(634^{\circ} \mathrm{F}\right)$, that the Dragon reactor had an outlet temperature of $750^{\circ} \mathrm{C}\left(1382^{\circ} \mathrm{F}\right)$ and an inlet temperature and pressures ( 150 psia) close to those chosen for this preliminary cooling system design of the HFFPR. The HFFPR reactor fuel element design, however, is expected to be quite different from these other reactors and may impose additional restrictions on the cooling system parameters.

Helium properties in the reactor core will be taken as those at the mean temperature of $454^{\circ} \mathrm{C}\left(850^{\circ} \mathrm{F}\right)$. Since the reactor power is $6.5 \mathrm{MW}(\mathrm{t})$, the helium mass flow rate is found from the formula

$$
\dot{m}_{n}=\left(\frac{d Q}{d t}\right)\left(\frac{1}{c_{p} \Delta T}\right)
$$

where

$$
\Delta T=\text { temperature drop across the reactor in degrees Fahrenheit }
$$




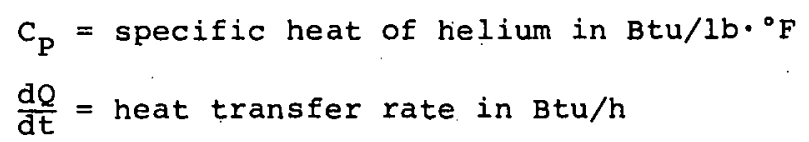

Inserting the appropriate values yields a helium mass of $3.19 \mathrm{~kg} / \mathrm{s}(25,305$ $1 \mathrm{~b} / \mathrm{h})$. The portion of the reactor core's cross-sectional area which is covered by the helium is simply the cross-sectional area of the core times the volume fraction. Thus the approximate mean core velocity can be obtained from the formula

$$
\mathrm{v}_{\mathrm{m}}=\frac{\dot{\mathrm{m}}_{\mathrm{n}}}{\rho \dot{\mathrm{A}}_{\mathrm{f}}}
$$

where

$$
\begin{aligned}
\rho & =\text { helium density in } 1 \mathrm{~b} / \mathrm{ft}^{3} \\
A_{f} & =\text { helium cross-sectional. flow area in the core in } \mathrm{ft}^{2}
\end{aligned}
$$

This formula yields a mean core velocity of about $12.4 \mathrm{~m} / \mathrm{s}(40.7 \mathrm{ft} / \mathrm{s})$. In the following calculations, a mean velocity of $12.2 \mathrm{~m} / \mathrm{s}(40 \mathrm{ft} / \mathrm{s})$ will be used for the core. Since the specific volume of the helium is different at different temperatures, the core outlet velocity will not be the same as the core inlet velocity. 'l'his velocity difference affects the enthalpy change across the reactor according to the formula: 16

$$
h_{0}-h_{I}=c_{P}\left(T_{0}-T_{I}\right)+\frac{\left(v_{u}^{2}-v_{I}^{2}\right)}{2 g}
$$

where

$$
\begin{aligned}
& h_{0}=\text { output enthalpy in Btu/lb } \\
& h_{I}=\text { input enthalpy in Btu/lb } \\
& T_{0}=\text { output temperature in degrees Fahrenheit } \\
& T_{I}=\text { input temperature in degrees Fahrenheit } \\
& C_{P}=\text { specific heat of helium in } \mathrm{Btu} / \mathrm{Ib} \cdot{ }^{\circ} \mathrm{F} \\
& g=\text { acceleration of gravity in } \mathrm{ft} / \mathrm{s}^{2} \\
& V_{0}=\text { output helium velocity } \\
& V_{I}=\text { input helium velocity }
\end{aligned}
$$

Using the formulas

$$
v_{o}=\frac{v_{m} s_{0}}{s_{m}}
$$


and

$$
V_{I}=\frac{v_{m} s_{I}}{s_{m}}
$$

where

$$
\begin{aligned}
& s_{0}=\text { output specific volume in } \mathrm{ft}^{3} / 1 \mathrm{~b} \\
& s_{I}=\text { input specific volume } \\
& s_{m}=\text { mean specific volume }
\end{aligned}
$$

it is found that the change in enthalpy due to the velocity difference is only about $93 \mathrm{~J} / \mathrm{kg}(0.04 \mathrm{Btu} / \mathrm{lb})$ and can be neglected compared to the entropy change of $2.02 \mathrm{MJ} / \mathrm{kg}(869: 4 \mathrm{Btu} / 1 \mathrm{~b})$ caused by the temperature drop.

The basic design for the helium-to-water heat exchanger will be of the U-tube type; as illustrated in Figure $\mathrm{C}-1$. The design parameters of this heat exchanger will be estimated with a linear model.

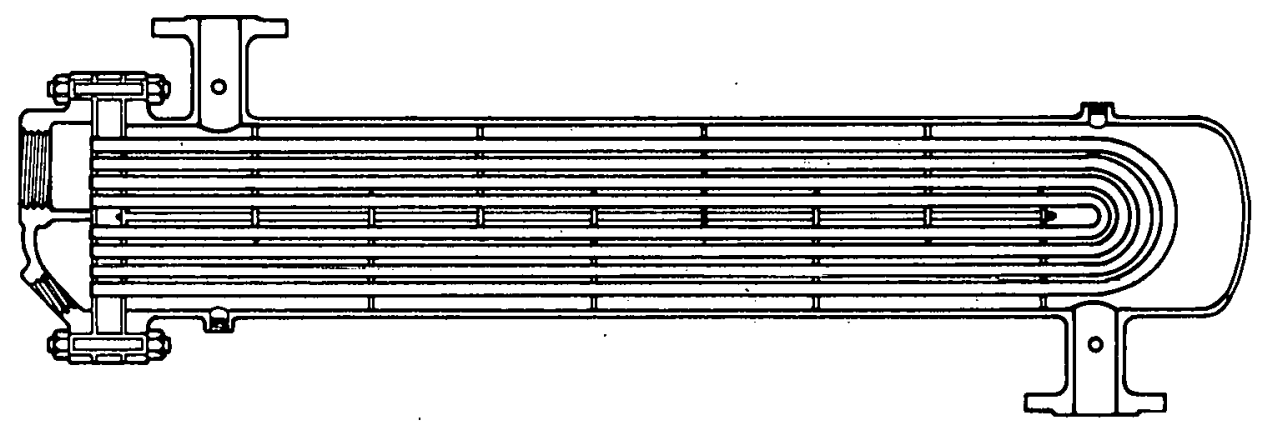

Figure C-1. U-Tube Heat Exchanger (Figure from Reference 11)

First, find the logarithmic mean temperature difference from the formulas 17

$$
\begin{aligned}
& \Delta T_{1}=T_{h_{1}}-T_{C_{1}} \\
& \Delta T_{2}=T_{h_{2}}={ }^{T}{ }_{c_{2}}
\end{aligned}
$$

and

$$
\Delta T=\frac{\Delta \mathrm{T}_{1}-\Delta \mathrm{T}_{2}}{\ln \left(\Delta \mathrm{T}_{1} / \Delta \mathrm{T}_{2}\right)}
$$


where

$$
\begin{aligned}
& T_{h_{1}}=\text { high temperature on the hot side } \\
& T_{h_{2}}=\text { low temperature on the hot side } \\
& T_{C_{1}}=\text { high temperature on the cold side } \\
& { }_{C_{C_{2}}}=\text { low temperature on the cold side }
\end{aligned}
$$

For the hot side of the heat exchanger, $\mathrm{T}_{\mathrm{h}_{1}}$ is $649^{\circ} \mathrm{C}\left(1200^{\circ} \mathrm{F}\right)$ and $\mathrm{T}_{\mathrm{h}_{2}}$ is $260^{\circ} \mathrm{C}$ $\left(500^{\circ} \mathrm{F}\right)$; for the cold side, $\mathrm{T}_{\mathrm{C}_{1}}$ is $149^{\circ} \mathrm{C}\left(300^{\circ} \mathrm{F}\right)$ and $\mathrm{T}_{\mathrm{C}_{2}}$ is $93^{\circ} \mathrm{C}\left(200^{\circ} \mathrm{F}\right)$. All of these values are assumed. The logarithmic mean temperature difference $\Delta T$ is then found to be $286^{\circ} \approx\left(346^{\circ} .4^{\circ} \mathrm{F}^{\prime}\right)$. The correction factor for the heat exchangers operating at these temperatures is very close to unity; consequently, the $\Delta T$ value will be assumed as approximately correct.

The properties of helium at the mean shell temperature of $454^{\circ} \mathrm{C}\left(850^{\circ} \mathrm{F}\right)$ and 150 psia are as follows:

$$
\begin{aligned}
& \rho=0.66 \mathrm{~kg} / \mathrm{m}^{3}\left(0.041 \mathrm{lb} / \mathrm{ft}^{3}\right) \text { (density) } \\
& c_{p}=5.2 \mathrm{~kJ} / \mathrm{kg} \cdot \mathrm{K}\left(1.242 \mathrm{Btu} / \mathrm{lb} \cdot{ }^{\circ} \mathrm{F}\right) \text { (specific heat) } \\
& M=38 \mu \mathrm{Pa} \cdot \mathrm{s}\left(9.234 \times 10^{-2} \mathrm{lb} / \mathrm{ft} \cdot \mathrm{h}\right) \text { (viscosity) }
\end{aligned}
$$

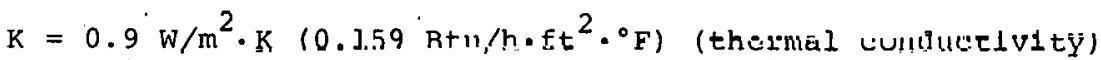

The outside film heat transfer cocfficient for the helium around the tubes can be estimated with the formula

$$
h_{0}=\left(c_{p} \rho V\right)\left(\frac{a_{4}}{F_{s}}\right)\left(\frac{1}{\mathrm{R}^{1-N_{O}}}\right)\left(\frac{1}{p^{2 / 3}}\right)
$$

where

$$
\begin{aligned}
& R=\frac{V \rho D_{O}}{\mu}=\text { Reynolds number } \\
& P=\frac{\mu C}{k}=\text { Prandtl number } \\
& D=\text { outside tube diameter }
\end{aligned}
$$

Here the helium shell velocity will be assumed to be $9.1 \mathrm{~m} / \mathrm{s}(30 \mathrm{ft} / \mathrm{s})$. Eq. (C-9) then yields an outside film heat transfer coefficient of $364 \mathrm{~W} / \mathrm{m}^{2} \cdot \mathrm{K}(64.1 \mathrm{Btu} / \mathrm{h}$. $\left.\mathrm{ft}^{2} \cdot \mathrm{o} \mathrm{F}\right)$. For a gas, $\mathrm{a}_{4}$ was taken to be $0.33, \mathrm{~F}_{\mathrm{s}}$ to be 1.25 , and $\mathrm{N}_{0}$ to be 0.6 .15 
In order to get an estimate of the inside film heat transfer coefficient, the following properties of water at a mean temperature of $121^{\circ} \mathrm{C}\left(250^{\circ} \mathrm{F}\right)$ are needed : 15

$$
\begin{aligned}
\rho & =985 \mathrm{~kg} / \mathrm{m}^{3}\left(61.5 \mathrm{lb} / \mathrm{ft}^{3}\right) \text { (density) } \\
C_{p} & =4.23 \mathrm{~kJ} / \mathrm{kg} \cdot \mathrm{K}\left(1.01 \mathrm{Btu} / \mathrm{lb} \cdot{ }^{\circ} \mathrm{F}\right) \quad(\text { specific heat) } \\
\mu & =245 \mu \mathrm{Pa} \cdot \mathrm{s}\left(0.165 \times 10^{-3} \mathrm{lb} / \mathrm{ft} \cdot \mathrm{s}\right) \text { (viscosity) } \\
\mathrm{k} & =2.24 \mathrm{~W} / \mathrm{m}^{2} \cdot \mathrm{K}\left(0.394 \mathrm{Btu} / \mathrm{h} \cdot \mathrm{ft}^{2} \cdot{ }^{\circ} \mathrm{F}\right) \text { (thermal conductivity) }
\end{aligned}
$$

The inside film heat transfer coefficient is determined from the formula

$$
h_{i}=\left(c_{p} \rho v\right)\left(\frac{a_{3}}{F_{s}}\right)\left(\frac{1}{R^{1-N_{i}}}\right)\left(\frac{1}{p^{2 / 3}}\right)
$$

where $a_{3}$ is chosen as $0.023, F_{S}$ as 1.25 , and $N_{i}$ as 0.8 .15 If the preceding values for water properties are substituted into this formula and the velocity of the water in the tubes is assumed to be $0.6 \mathrm{~m} / \mathrm{s}(2 \mathrm{ft} / \mathrm{s})$, an inșide film heat transfer coefficient of $4.134 \mathrm{~kW} / \mathrm{m}^{2} \cdot \mathrm{K}\left(728 \mathrm{Btu} / \mathrm{h} \cdot \mathrm{ft}^{2} \cdot{ }^{\circ} \mathrm{F}\right)$ results.

If fouling resistance is neglected, the overall inside heat transfer coefficient for the helium-to-water heat exchanger is given by the formulal5

$$
\frac{1}{u_{i}}=\frac{1}{h_{i}}+\frac{\left(D_{0}-D_{i}\right) / 2}{k_{w}\left(D_{0} / D_{i}\right)}+\frac{1}{h_{0}\left(D_{0} / D_{i}\right)}
$$

where

$$
\begin{aligned}
& \mathrm{u}_{\mathrm{i}}=\text { overall heat transfer coefficient in } \mathrm{Btu} / \mathrm{h} \cdot \mathrm{ft} \mathrm{t}^{2} \cdot{ }^{\circ} \mathrm{F} \\
& \mathrm{D}_{0}=\text { outside tube diameter } \\
& \mathrm{D}_{\mathrm{i}}=\text { inside tube diameter } \\
& \mathrm{K}_{\mathrm{w}}=\text { thermal conductivity of the Incoloy } 800 \mathrm{H} \text { tube walls at a } \\
& \text { mean temperature of } 121^{\circ} \mathrm{C}\left(250^{\circ} \mathrm{F}\right)
\end{aligned}
$$

Given a value of 96 for $\mathrm{K}_{w^{\prime}}$ the overall inside heat transfer coefficient is found to be $450 \mathrm{~W} / \mathrm{m}^{2} \cdot \mathrm{K}\left(79.2 \mathrm{Btu} / \mathrm{h} \cdot \mathrm{ft} \mathrm{t}^{2} \cdot{ }^{\circ} \mathrm{F}\right)$.

'l'he following formulas are needed to determine the overall heat transfer area :

$$
\begin{aligned}
& U_{0} A_{0}=U_{i}^{A_{i}} \\
& U_{0} A_{0}=\frac{d Q / d t}{\Delta T}
\end{aligned}
$$


where

$$
\begin{aligned}
& U_{0}=\text { overall outside heat transfer coefficient in } \mathrm{Btu} / \mathrm{h} \cdot \mathrm{ft}{ }^{2} \cdot{ }^{\circ} \mathrm{F} \\
& \mathrm{A}_{0}=\text { overall outside heat transfer area in } \mathrm{ft}^{2} \\
& \mathrm{dQ} / \mathrm{dt}=\text { rate of heat transmission in } \mathrm{Btu} / \mathrm{h} \\
& u_{i}=\text { overall inside heat transfer coefficient } \\
& A_{i}=\text { overall inside heat transfer area }
\end{aligned}
$$

Eq. (C-15) yields $\mathrm{U}_{0} \mathrm{~A}_{0}$ as $40,264 \mathrm{Btu} / \mathrm{h} \cdot{ }^{\circ} \mathrm{F}$; the value of $\mathrm{A}_{i}$ is then found from

$$
A_{i}=\frac{U_{0} A_{0}}{I_{1}}
$$

to be $47.2 \mathrm{~m}^{2}\left(508.37 \mathrm{Ft}^{2}\right)$

The mass flow rate of the water in the tubes is found from the equation

$$
\dot{\mathrm{m}}_{w}=\frac{\mathrm{dQ} / \mathrm{dt}}{\left(\mathrm{h}_{0}-\mathrm{h}_{\mathrm{i}}\right)}
$$

where

$$
\begin{aligned}
& \mathrm{h}_{\mathrm{g}}=\text { enthalpy of output water in } \mathrm{R}+11 / 1 \mathrm{~h} \text { at } 300^{\circ} \mathrm{F} \\
& \mathrm{h}_{\mathrm{i}}=\text { enthalpy of input water in Btu/lb at } 200^{\circ} \mathrm{F}
\end{aligned}
$$

If the values of enthalpy are taker to be 269.87 and 168.40 , respectively, the water mass flow rate is $27.32 \mathrm{~kg} / \mathrm{s}(216,813 \mathrm{lb} / \mathrm{h})$. Based on this, the overall cross section as seen by the water in the heat exchanger can be found from

$$
A_{C}=\frac{\dot{m}_{w}}{\rho V}
$$

This formula gives a value of $0.05 \mathrm{~m}^{2}\left(0.49 \mathrm{ft}^{2}\right)$. The number of tubes necessary to show this cross section is determined by

$$
N=\frac{\left(A_{C}\right)(4)}{(\Pi)\left(D_{i}\right)^{2}}
$$

The number of tubes in the heat exchanger is 160. The length of the tubes in the heat exchanger can now be found from the formula

$$
L=\frac{A_{i}}{\pi D_{i}^{N}}
$$


which yields a value of approximately 5 metres (16.3 feet). The tubes which are bent into a U-shape will then give a length of about 2.4 metres ( 8 feet). Inclusion of the shell, piping fixtures, etc., will bring the final length to about 3 metres (10 feet).

The cross section of the heat exchanger depends on the diameter, spacing, and arrangement of the tubes. It has been assumed that a triangular lattice (illustrated in Figure $\mathrm{C}-2$ ) will be used. The pitch ratio, $\sigma$, is defined by the formula

$$
\sigma=\frac{2}{D_{0}}
$$

where $D_{0}$ is the outer diameter of the tubes and a clearance between the tubes of $6 \mathrm{~mm}(0.25 \mathrm{inch})$ is assumed. 15 since $D_{0}$ is $27 \mathrm{~mm}$ ( 1.05 inches), $\mathrm{z}$ will have a value of $33 \mathrm{~mm}$ ( 1.3 inches); therefore, $\sigma$ has a value of 1.23 .

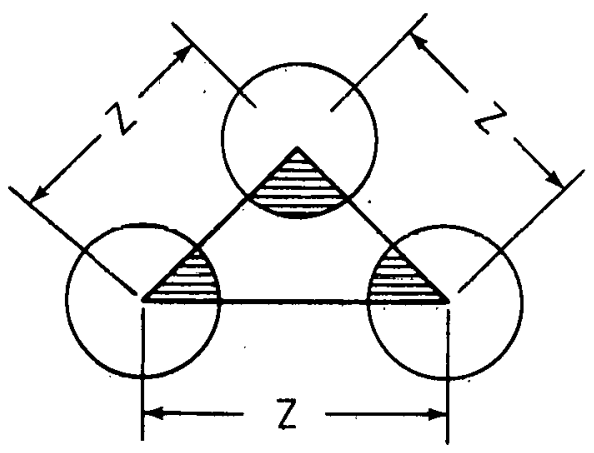

Figure C-2. Triangular Lattice

The ratio of the heat transfer surface to the total volume is defined by the equation 15

$$
s=\frac{3.63}{\sigma^{2} D_{0}}
$$

If the preceding values given for $O$ and $D_{0}$ arc substituted into Eq. (C-22), the value of $\mathrm{S}$ is $27.42 \mathrm{ft}^{2} / \mathrm{cm}-\mathrm{ft}$. The heat transfer surface can be found from the formula

$$
A_{0}=N M D_{O} L
$$

which yields $66.6 \mathrm{~m}^{2}\left(716.9 \mathrm{ft}^{2}\right)$ when the proper values are inserted. Let $A_{c r t}$ be the cross-sectional area of the tube bundle in the heat exchanger. The area 
can be derived from the formula

$$
A_{\text {crt }}=\frac{2 A_{O}}{S L}
$$

When the preceding values are substituted into it, Eq. (C-24) yields $0.3 \mathrm{~m}^{2}$ (3.2 $\mathrm{ft}^{2}$ ) for the cross-sectional area of the heat exchanger. This is equivalent to a diameter of about 0.6 metre ( 2 feet). The shell will increase the diameter so that the actual heat exchanger will be around 0.8 metre ( 2.5 feet) in diameter.

These calculations indicate that the helium-to-water heat exchanger will have parameters of the sizes indicated in Table C-I,

TARTE E-I

Helium Heat Exchanger Parameters

\section{$\underline{\text { Parameters }}$}

$\Delta \mathrm{T}$ :

ho

$\mathrm{h}_{i}$

$u_{i}$

U

$\mathrm{N}$

L

$\mathrm{D}$
Values

$285.8^{\circ} \mathrm{O}\left(54 G .4^{n} \mathrm{~F}\right)$

$364 \mathrm{~W} / \mathrm{m}^{2} \cdot \mathrm{K}\left(64.1 \mathrm{Btu} / \mathrm{h} \cdot \mathrm{ft} \mathrm{t}^{2} \cdot{ }^{\circ} \mathrm{F}\right)$

$4.137 \mathrm{~kW} / \mathrm{m}^{2} \cdot \mathrm{K}\left(728.5 \mathrm{Btu} / \mathrm{h} \cdot \mathrm{ft} \mathrm{t}^{2} \cdot{ }^{\circ} \mathrm{F}\right)$

$450 \mathrm{~W} / \mathrm{m}^{2} \cdot \mathrm{K} \quad\left(79.2 \mathrm{Btu} / \mathrm{h} \cdot \mathrm{ft} \mathrm{t}^{2} \cdot{ }^{\circ} \mathrm{F}\right)$

$324 \mathrm{~W} / \mathrm{m}^{2} \cdot \mathrm{K}\left(57 \mathrm{Btu} / \mathrm{h} \cdot \mathrm{ft} \mathrm{t}^{2} \cdot{ }^{\circ} \mathrm{F}\right)$

160 tubes

3 metres (10 fẹt)

0,8 met.rp $(2,5$ foot $)$

When the same methods of calculation given in Table C-I are applied, the parameters of the water-to-water secondary hcat exchanger are determined to be approximated by those indicated in Table C-II.

\section{TDRLE C-II}

Water Heat. Exchanger Parameter's

\section{Parameters}

$\Delta \mathrm{I}^{\prime}$

ho

hi

$\mathrm{u}_{\mathrm{i}}$

$\mathrm{U}^{\mathrm{i}}$

$\mathrm{N}$

L

D
Values

$50,5^{\circ} \mathrm{C}\left(123^{\circ} \mathrm{F}\right)$

$4.68 \mathrm{~kW} / \mathrm{m}^{2} \cdot \mathrm{K} \quad\left(824 \mathrm{Btu} / \mathrm{h} \cdot \mathrm{ft}^{2} \cdot{ }^{\circ} \mathrm{F}\right)$

$4.137 \mathrm{~kW} / \mathrm{m}^{2} \cdot \mathrm{K} \quad\left(728.5 \mathrm{Btu} / \mathrm{h} \cdot \mathrm{ft} \mathrm{t}^{2} \cdot{ }^{\circ} \mathrm{F}\right)$

$2.57 \mathrm{~kW} / \mathrm{m}^{2} \cdot \mathrm{K} \quad\left(452 \mathrm{Btu} / \mathrm{h} \cdot \mathrm{ft}^{2} \cdot{ }^{\circ} \mathrm{F}\right)$

$1.89 \mathrm{~kW} / \mathrm{m}^{2} \cdot \mathrm{K}\left(333 \mathrm{Btu} / \mathrm{h} \cdot \mathrm{ft}^{2} \cdot{ }^{\circ} \mathrm{F}\right)$

163 tubes

2.7 metres (9 feet)

0.9 metre ( 3 feet) 
Finally, the pressures and mass flow rates for the primary and secondary heat exchangers are given in Table C-III.

TABLE C-III

Pressures and Mass Flow Rates

Helium Heat Exchanger

$\begin{array}{ll}\text { Helium pressure primary } & 150 \mathrm{psia} \\ \text { Water pressure secondary } & 150 \mathrm{psia} \\ \text { Mass flow of helium } & 3.2 \mathrm{~kg} / \mathrm{s}(25,305 \mathrm{lb} / \mathrm{h}) \\ \text { Mass flow of water } & 27.3 \mathrm{~kg} / \mathrm{s}(216,813 \mathrm{lb} / \mathrm{h})\end{array}$

Water Heat Exchanger

Primary water pressure $\quad 150$ psia

Secondary water pressure 25 psia

Mass flow in primary $27.3 \mathrm{~kg} / \mathrm{s}(216,813 \mathrm{lb} / \mathrm{h})$

Mass flow in secondary $\quad 55.5 \mathrm{~kg} / \mathrm{s}(440,528.6 \mathrm{lb} / \mathrm{h})$

Since Sandia Laboratories has no computer codes for the analysis of heat exchangers, the decision was made to solicit computer code analyses from several different manufacturers. Since the above analysis is ideal. and involves many assumptions; the results obtained from the computer codes developed by the manufacturers would seem to be more reliable.

An analysis was performed by APCO Nuclear to determine approximate design parameters for the helium-to-water heat exchanger. The following are the basic design parameters which were obtained:

- Helium

Temperature in - $704^{\circ} \mathrm{C}\left(1300^{\circ} \mathrm{F}\right)$

Temperature out -- $315^{\circ} \mathrm{C}\left(600^{\circ} \mathrm{F}\right)$

Fiessure … $1 \mathrm{MPa}$ (10 atm)

Flow Rate -- $3.15 \mathrm{~kg} / \mathrm{s}(25,000 \mathrm{lb} / \mathrm{h})$

- Cooling Water

Temperature in $-93^{\circ} \mathrm{C}\left(200^{\circ} \mathrm{F}\right)$

Temperature out -- $149^{\circ} \mathrm{C}\left(300^{\circ} \mathrm{F}\right)$

Pressure -- $1 \mathrm{MPa}$ (10 atm)

Flow Rate - $24.1 \mathrm{~kg} / \mathrm{s}$ ( $191,000 \mathrm{lb} / \mathrm{h}$ )

- Tower water

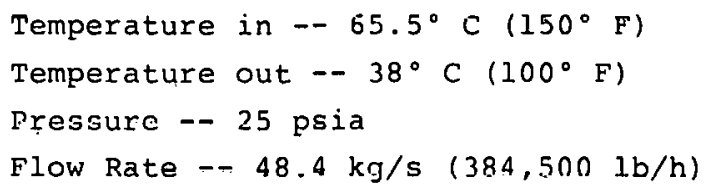


Outer Diameter -- 0.8 metre $(2.5$ feet $)$

Length -- 3.2 metres $(10.5$ feet)

Space Required - 1.2 by 1.2 by 3.4 metres ( 4 by 4 by 11 feet)

APCO estimates the cost of the primary heat exchanger to be from $\$ 75,000$ to $\$ 100,000$.

APCO has indicated that the secondary water-to-water heat exchanger is practically an off-the-shelf item and could be supplied for about $\$ 25,000$. It would have an outer diameter of about 0.6 metre ( 2 feet) and a length of about 3 metres (10 feet).

Westinghouse has proposed the system shown in Fiqure c-3. The heated holium enters the primary heat exchanger where heat is transferred to pressurized water. The heated water is then transferred to a reboiler heat exchanger where the heat is transferred by vaporization of the water. The resulting steam is then passed to a cooling tower where the steam is condensed and subcooled.

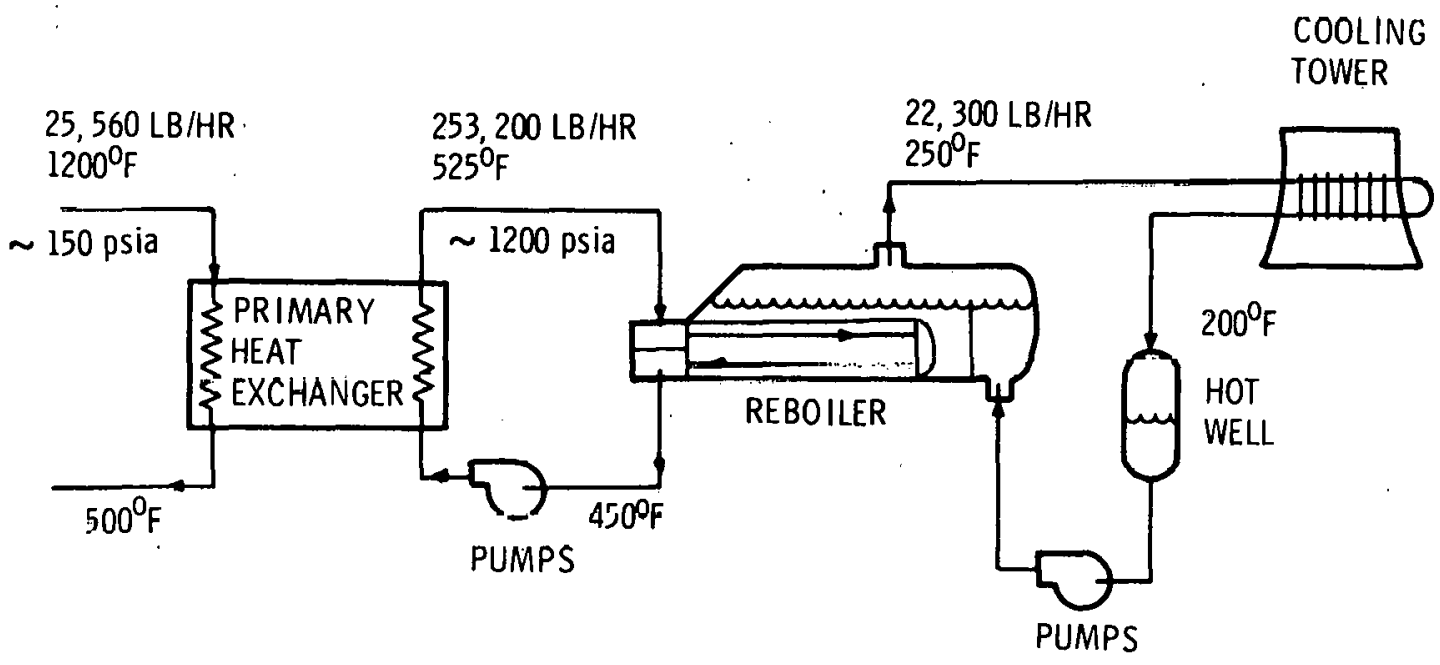

Figure C-3. Westinghouse Cooling System with Reboiler

For a $6.5 \mathrm{MW}(t)$ heat load, the primary heat exchanger would require about 44 helical coiled tubes, each with an outside diameter of $19 \mathrm{~mm}(0.75$ inch) and a length of 18 metres $(60$ feet). The heat exchanger matrix would have a diameter of about 0.6 metre ( 2 feet) and a length of 1.8 metres ( 6 feet). The shell would bc about 0.9 metre ( 3 feet in diameter and 2.7 metres $(9$ feet) long.

The reboiler would require about 350 tubes, each with an outside diameter of $19 \mathrm{~mm}(0.75 \mathrm{inch})$ and a length of 4.6 metres (15 feet). The reboiler shell would be about 0.9 metre ( 3 feet) in diameter and 6 metres ( 20 feet) long. The water piping between the primary and reboiler heat exchangers could be $13 \mathrm{~cm}$ (5 inches) in diameter. Westinghouse did not provide any cost information. 
Wyatt Industries, Inc., suggested a two-pass U-bend with gas flow directed yia internal pipe within the channel into the center of the tube field. The gas would exit through tubes on the periphery of the field and leave by means of a conventional channel nozzle. The internal pipe would be designed for a differential pressure of about $137.9 \mathrm{kPa}(20 \mathrm{psi})$. This type of design offers the advantage of not having a shell expansion joint for operation without water flow. In addition, a minimum amount of weldment is exposed to the $704^{\circ} \mathrm{C}\left(1300^{\circ} \mathrm{F}\right) \mathrm{gas}$. This might be particularly advantageous if the helium is difficult to confine. This unit would have an outside diameter of about $76 \mathrm{~cm}$ (30 inches) and have an overall length of 3.6 metres (12 feet). The unit would require about $0.1 \mathrm{~m}^{3} / \mathrm{s}$ $(1750 \mathrm{gal} / \mathrm{min})$ of wațer and would cost about $\$ 50,000$.

In all these calculations, including the very elementary linear calculation, the size of both heat exchangers ranges from 0.6 to 0.9 metre ( 2 to 3 feet) for the diameter and from about 2.7 to 4.6 metres ( 9 to 15 feet) for the length. Consequently, it is certain that there will be no trouble in fitting these units into the SERF building and its proposed additions.

Based on all these considerations, a number of nominal operating conditions for the proposed HFFPR have been suggested. These are illustrated in Figure c-4.
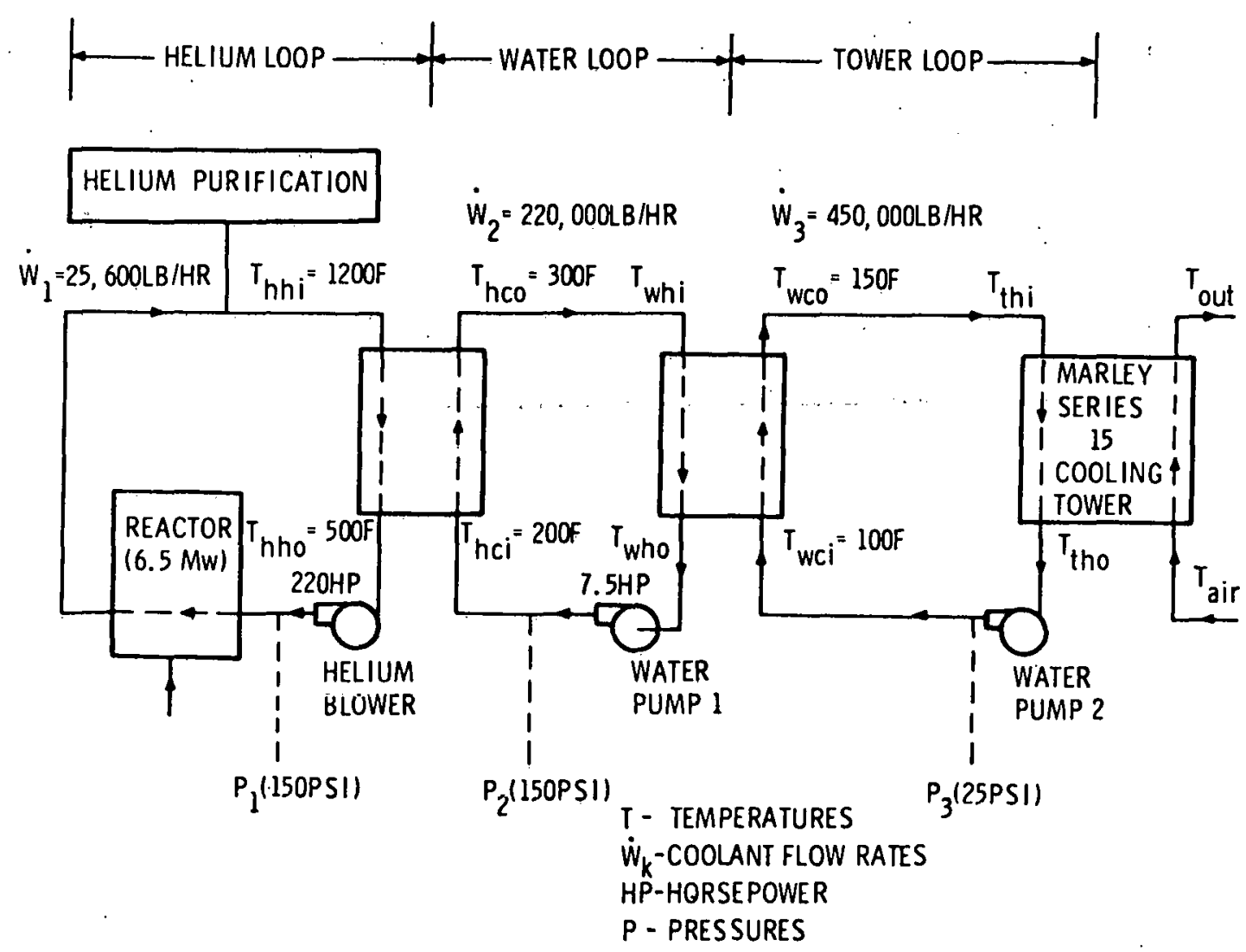

Figure C-4. HFFPR System Components and Nominal Design Conditions 
APPENDIX D

Pump Design for the HFFPR Cooling System

MTI has had considerable experience in the manufacture of helium blowers. It was this company which manufactured the blowers for the UHTREX experiment at Los Alamos and is currently designing similar blowers for Union Carbide and ORNL. The new blowers have the same structural design as those used in UHTREx. This design is illustrated in Figure $D-1 .{ }^{7}$ The exact measurements of the new blower are presented in Figures $\mathrm{D}-2$ and $\mathrm{D}-3.18$

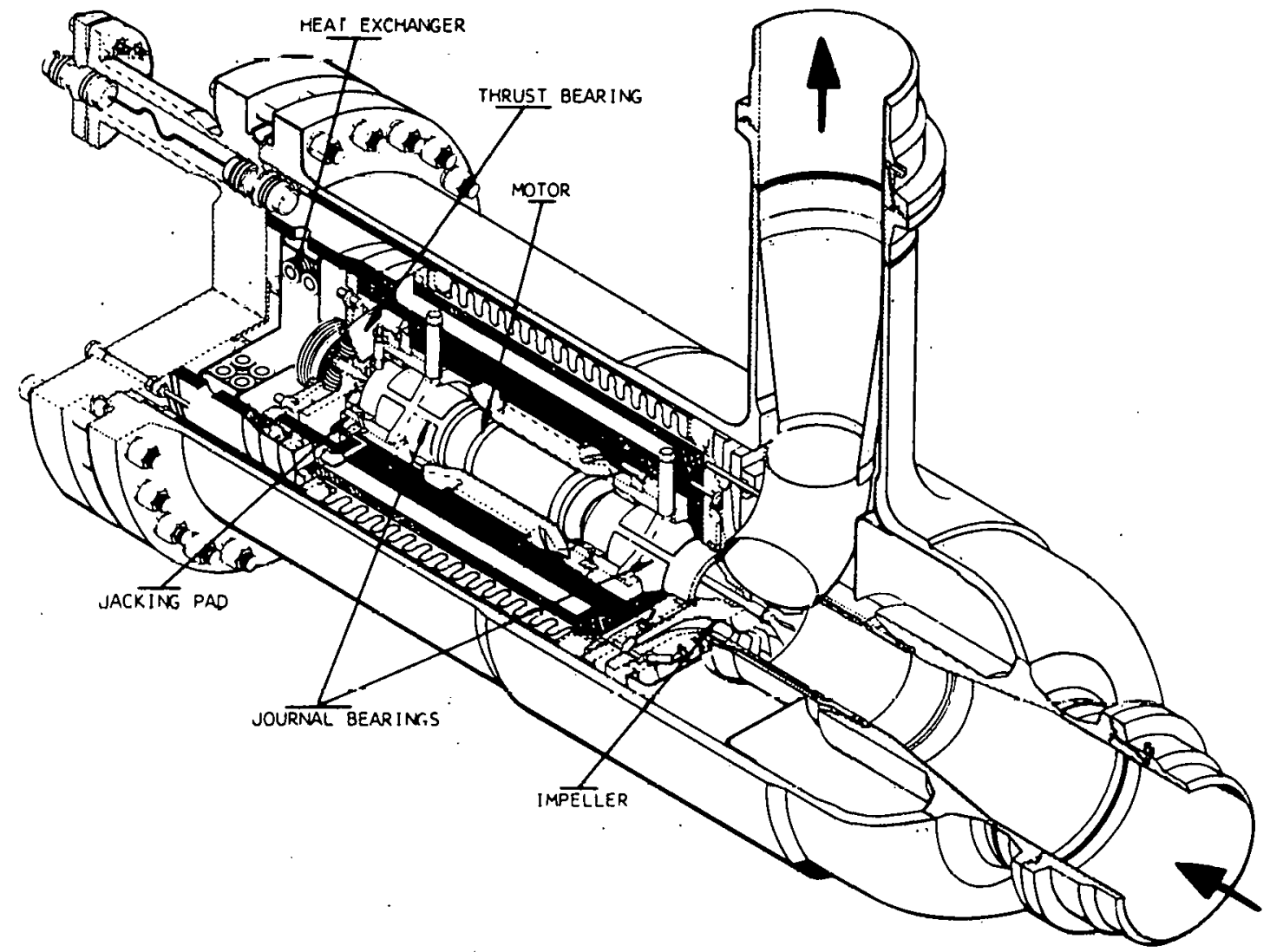

Figure D-1. Coolant Loop Blower

The circulator can easily handle $3.3 \mathrm{~kg} / \mathrm{s}(26,000 \mathrm{lb} / \mathrm{h})$ of helium at 150 psia and $315^{\circ} \mathrm{C}\left(600^{\circ} \mathrm{F}\right)$ with $a$ head rise between 17 and $34 \mathrm{kPa}(2.5$ and 5 psi). Power would be approximately $82 \mathrm{~kW}(110 \mathrm{hp})$ at. $17 \mathrm{kPa}(2.5 \mathrm{psi})$ head and $164 \mathrm{~kW}$ (220 hp) at $34 \mathrm{kPa}(5 \mathrm{psi})$ head. 


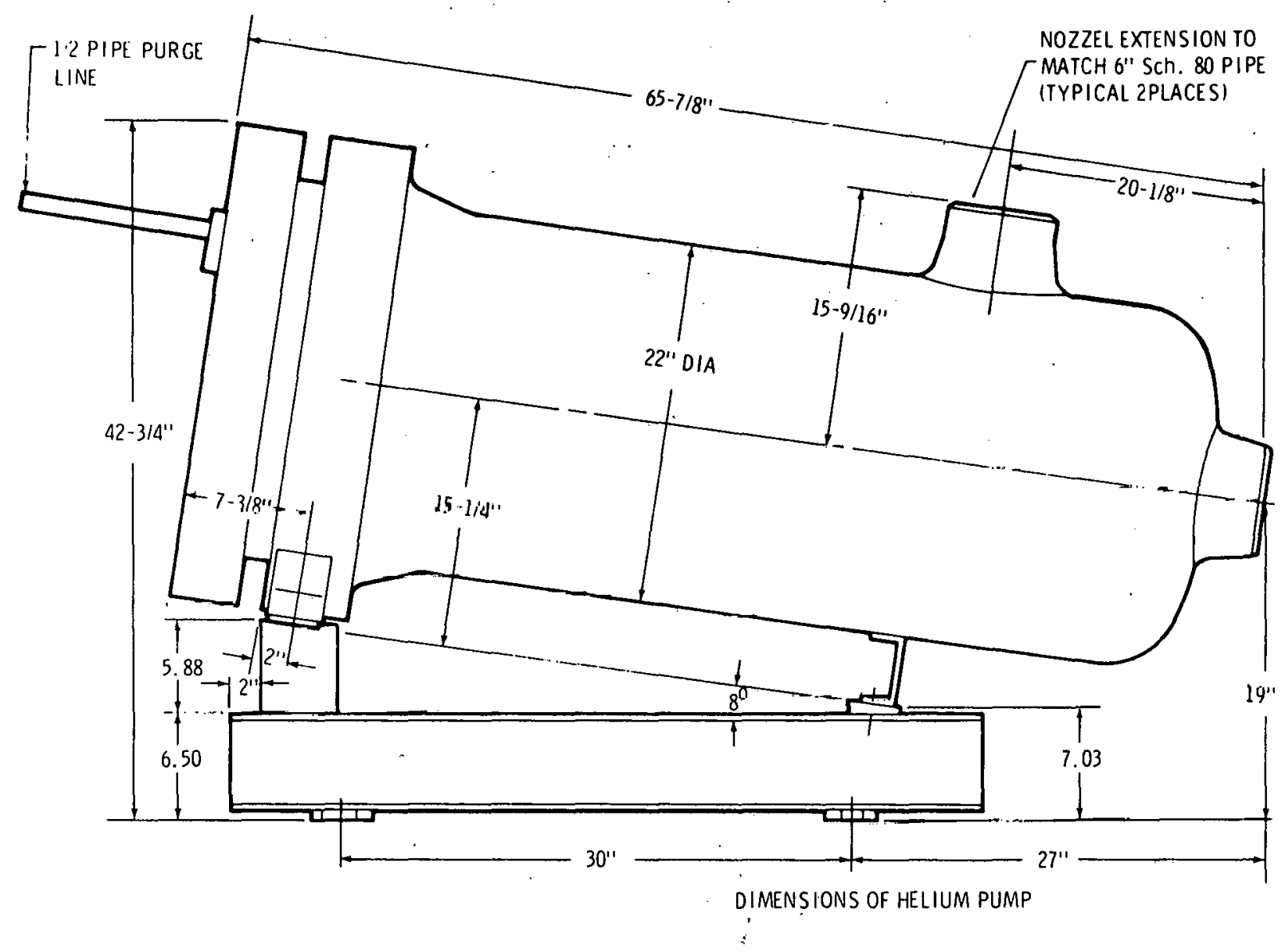

Figure D-2. Dimensions of Helium Pump

The estimated cost of the blower will be approximately $\$ 450,000$. This price does not include the hlgh-frequency $200-\mathrm{Hz}$ power supply which would cost approximately $\$ 75,000$.

The pump between the heat exchangers, referred to as pump 1, wj.1, have to liandle about $28 \mathrm{~kg} / \mathrm{s}(220,000 \mathrm{lb} / \mathrm{h})$. The cooling tower pump, referred to as pump 2 , will handle $57 \mathrm{~kg} / \mathrm{s}(450,000 \mathrm{lb} / \mathrm{h})$. The dynamic heads for these pumps can only be determined after a complete analysis of the cooling system.

For the purpose of cost estimation, pump 1 will be assumed to have a dynamic head of 15 metres ( 50 feet). This requirement can be satisfied by an Aurora Pump, $3 \times 4 \times 10 \mathrm{~B}$, series 410 . The motor will be $5.6 \mathrm{~kW}$ (7.5 hp) and will cost about \$1700. Pump 2 will be assumed to have a dynamic head of 46 metres (150 feet). This pump can be an Aurora Pump, $5 \times 6 \times 15$, series 413 and will cost $\$ 3,000.19$ These pumps will be not more than 0.9 metre ( 3 feet) tall and will occupy a space not greater than $0.2 \mathrm{~m}^{2}\left(2.5 \mathrm{ft}^{2}\right)$. They will stand in a vertical position. 


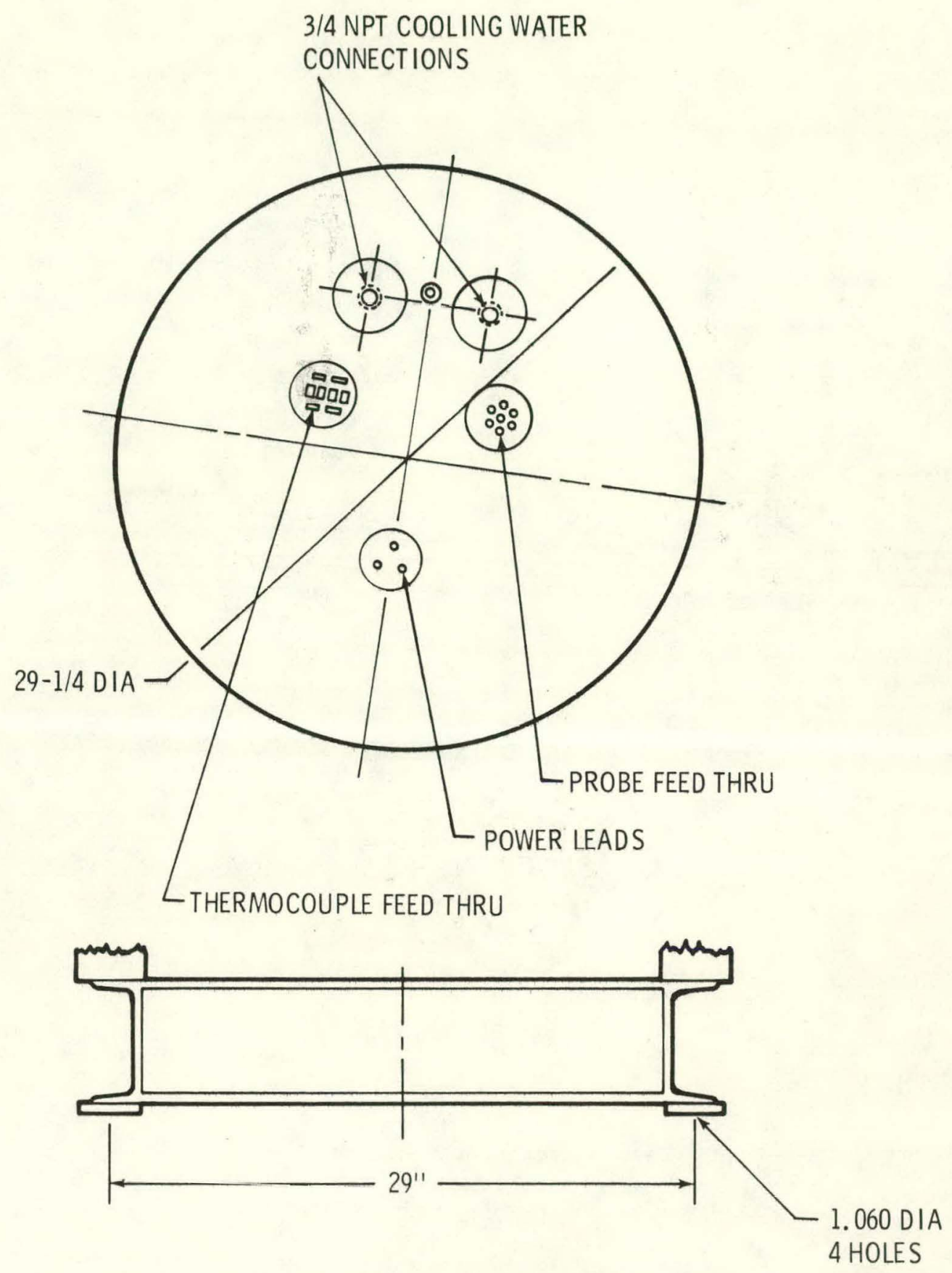

Figure D-3. Cross-Sectional Dimensions of the Helium Pump 
Figure D-4 presents three views of the water pump configuration. The pumps used at HFFPR will operate at a speed of $1750 \mathrm{rpm}$. Pump 2 will be rated at about $37 \mathrm{~kW}(50 \mathrm{hp})$.
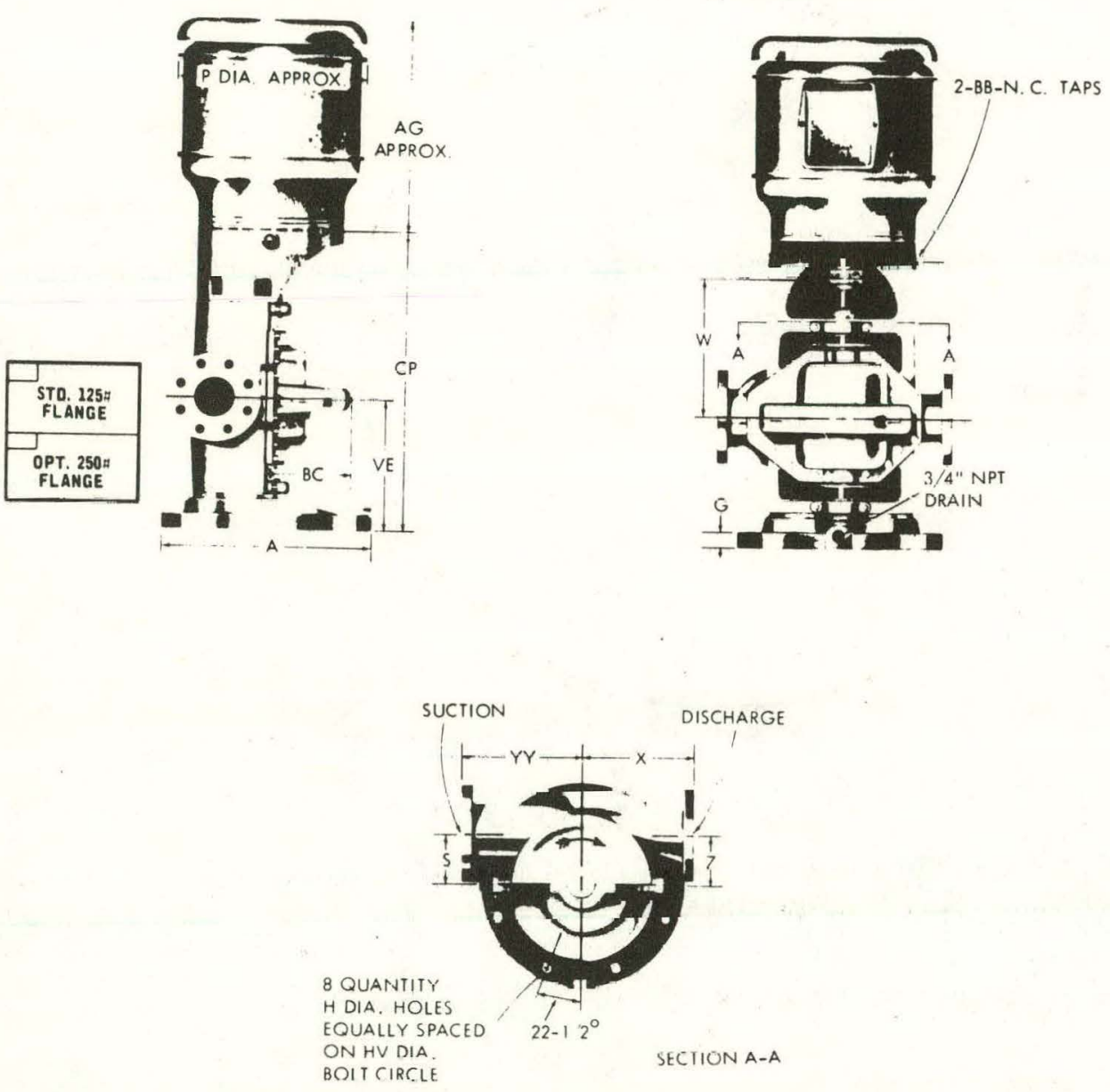

Figure D-4. Water Pump Configuration 
APPENDIX E

The HFFPR Cooling Tower

The cooling tower will have to $\operatorname{cool} 57 \mathrm{~kg} / \mathrm{s}(450,000 \mathrm{lb} / \mathrm{h})$ of water ranging in temperature from $38^{\circ} \mathrm{C}$ to $65^{\circ} \mathrm{C}\left(100^{\circ} \mathrm{F}\right.$ to $\left.150^{\circ} \mathrm{F}\right)$. It should be a forced draught cooling tower of the configuration illustrated in Figure E-1. The requirement will be satisfied by a Marley, Series 15, tower, which sells for about $\$ 12,000$. It will cover an area 6.1 by 4.9 metres ( 20 by 16 feet) and will stand 5.2 metres (17 feet) high. The motor which drives the fan will be $15 \mathrm{~kW}(20 \mathrm{hp}) .20$ 


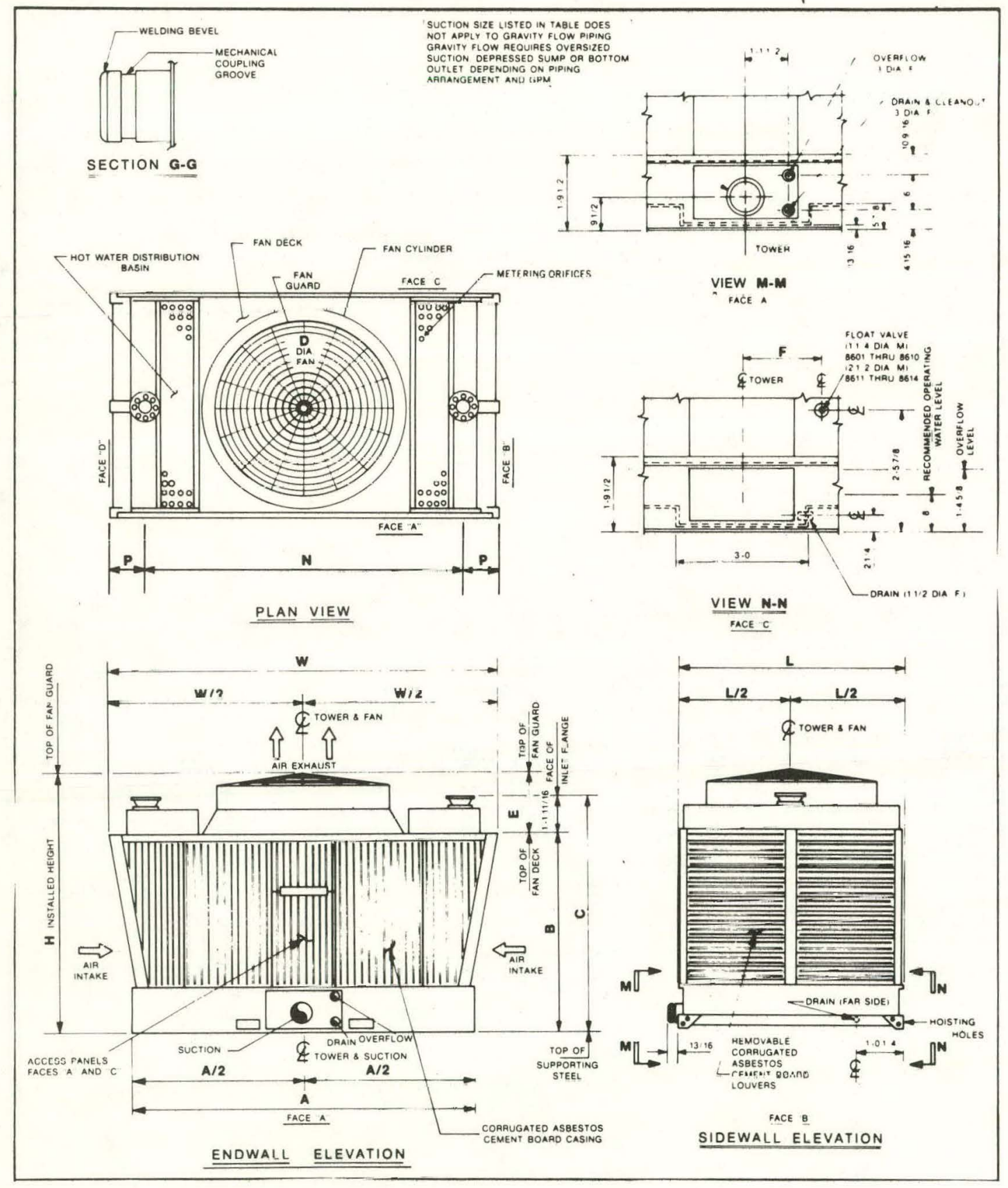

Figure E-1. Cooling Tower Configuration 


\section{APPENDIX F \\ The SERF Reactor Vessel as a Component of the HFFPR}

The SERF reactor vessel, located in Building 6580, is encased in very strong concrete and will be both difficult and expensive to remove. Consequently, it would be desirable to include it in. the HFFPR design.

The original reactor generated very low temperatures on the order of $49^{\circ} \mathrm{C}$ $\left(120^{\circ} \mathrm{F}\right)$. The new reactor will have an outlet temperature of $649^{\circ} \mathrm{C}\left(1200^{\circ} \mathrm{F}\right)$. The SERF reactor vessel was designed to withstand $1 \mathrm{MPa}$ (150 psi) without distortion and not to rupture below $2.76 \mathrm{MPa}(400 \mathrm{psi}) .^{2 l}$ It is important to determine what kind of pressures the vessel would be subjected to if an attempt were made to use it in direct conjunction with the HFFPR.

The portion of the SERF vessel embedded in concrete is illustrated in Figure F-1. If it is assumed that the lower portion of the vessel is subjected to a temperature of $649^{\circ} \mathrm{C}\left(1200^{\circ} \mathrm{F}\right)$, a quick estimate of the hoop pressure the vessel will experiencc can be obtained from the formula

$$
P=\frac{E h(\alpha) \Delta T}{R}
$$

where

$$
\begin{aligned}
\mathrm{P} & =\text { hoop pressure } \\
\mathrm{E} & =\text { Young's modulus }\left(\simeq 30 \times 10^{6} \text { psi }\right) \\
\alpha & =\text { expansion coefficient }\left(\simeq 7 \times 10^{-6}{ }^{\circ} \mathrm{F}^{-1}\right) \\
\dot{\Delta T} & =\text { temperature ditference } \\
\mathrm{R} & =\text { shell radius } \\
\mathrm{h} & =\text { shell thickness } \simeq 0.5 \text { inch }
\end{aligned}
$$

If a $593^{\circ} \mathrm{C}\left(1100^{\circ} \mathrm{F}\right)$ drop of temperature is assumed across the shell, the proseure obtained from F.q. (F-1) is $22.1 \mathrm{MPa}$ (3208 psi). This is a far greater pressure than the $2.76 \mathrm{MPa}(400 \mathrm{psi})$ it was designed to endure.

The shell is locked in concrete and little or no room is allowed for expansion. An estimate of the relative amount of expansion between the concrete 


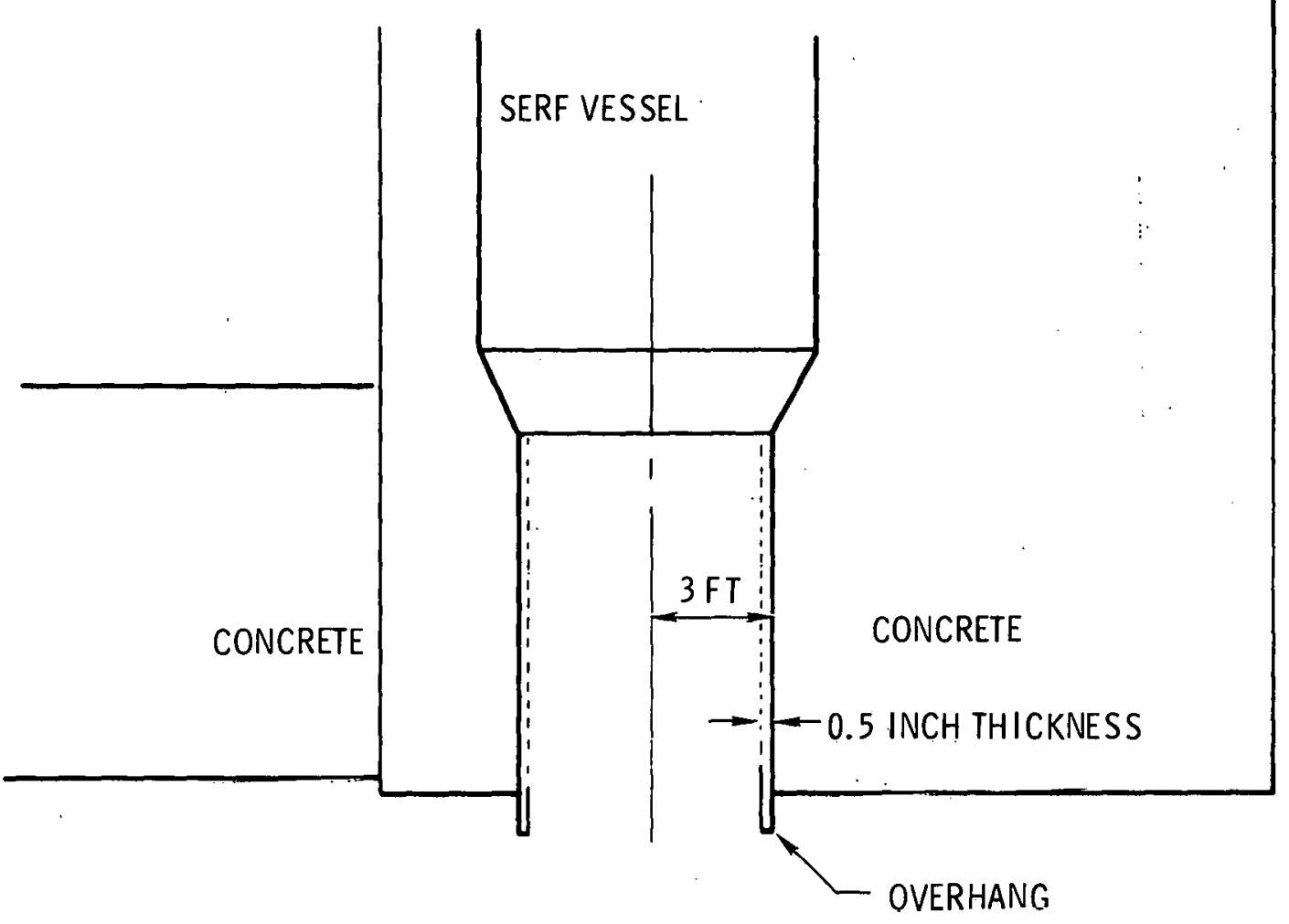

Figure F-1. Constraints on SERF Reactor Vessel

and the cylinder can be obtained frnm the gruation 22

$$
U(a)=\frac{-P\left(1-\mu^{2}\right)\left(\frac{a^{2}-b^{2}}{a}\right)}{E\left[(1+\mu)+(1-\mu)\left(\frac{b^{2}}{a^{2}}\right)\right]}
$$

where
$a=$ radius of the cylinder
$\mathrm{P}=$ pressure in the cylinder
$\mu=$ Poisson's ratio
$E=$ Young's modulus ( $4 \times 10^{-6}$ for concrete)
$\mathrm{b}=$ cylinder thickness

For the concrete; an infinite thickness will be assumed; therefore,

$$
\lim _{b \rightarrow \infty} U(a)=\frac{P a}{E}(1+\mu)
$$


When the proper values are substituted into Eq. (F-3), a value of $0.9 \mathrm{~mm}(0.037$ inch) for the amount of concrete expansion results. Eq. (F-2) gives the expansion of the cylinder or reactor vessel as approximately $10 \mathrm{~mm}(0.396 \mathrm{inch})$. Thus, it is obvious that great stresses will be produced.

Next, it is assumed that the shell is cut off at some distance $L$ from the concrete, as illustrated in Figure F-1. This produces what is commonly referred to as an overhang. An approximate idea of what happens here can be obtained by considering the following equation for a clamped thin cylinder:22

$$
\frac{d^{4} W}{d x^{4}}+4 B^{4} W=\frac{Z}{D}
$$

where

$$
\beta=\sqrt[4]{\frac{h E}{4(a)^{2} D}}=\left[\frac{3\left(1-\mu^{2}\right)}{a^{2} h^{2}}\right]^{\frac{1}{4}}
$$

and

$$
D=\frac{E h^{3}}{12\left(1-\mu^{2}\right)}
$$

The letter $\mathrm{z}$ indicates components of "either external or inertia load per unit area. In this instance, $\mathrm{z}$ will simply be taken as the thermal pressure in the shell. $\mathrm{A}$ solution for Eq. (F-4) takes the form

$$
\begin{aligned}
W(x)= & e^{B x}\left(A_{1} \sin B x+A_{2} \cos B x\right) \\
& +e^{-B x}\left(A_{3} \sin B x+A_{4} \cos B x\right)+\frac{P}{4 B^{4} D}
\end{aligned}
$$

Eq. (F-4) takes the same form as the equation for a beam on an elastic foundation. The moment is obtained by differentiating Eq. (F-7) to the 2nd derivative. An evaluation of the constants at boundary conditions gives a moment equation as

$$
M_{x}=\frac{P}{2 B^{2}}\left(\frac{\cosh ^{2} B L-\cos ^{2} B L}{\cosh ^{2} B L+\cos ^{2} B L}\right)
$$

Application of the preceding equations reveals that if $L$ is as small as 1 inch, the moment is 17,385 . The stress is obtained from the formula

$$
\sigma=\frac{6 \mathrm{M}}{\mathrm{h}^{2}}
$$


This formula yields a stress of $2.88 \mathrm{GPa}(417,240 \mathrm{psi})$. Thus, if the temperature reaches $649^{\circ} \mathrm{C}\left(1200^{\circ} \mathrm{F}\right)$, no overhangs can be allowed. This means that if the vessel is allowed to remain in the building with the HFFPR, it should be cut off at the concrete and the shell should never be subjected to a temperature greater $\operatorname{than} 177^{\circ} \mathrm{C}\left(350^{\circ} \mathrm{F}\right)$.

These restrictions which must be placed on the use of the SERF reactor vessel lead to the question: How should the SFRT reactor vessel be used with the HFFPR if indeed it should be used at all? In the original reactor, the yessel had many functions. It provided reactor containment, core access, and support and guides for the control rod drives. It also served as a shield against reactor radiation and as a part of the cooling system. In addition, it provided access parts for detectors, internal wiring, and other instrumentation, it permitted underwater fuel discharge to cutoff, pon, and it provided sluraye space for partially spent tuel elements or other radioactive sources. It may be possible to use the old vessel for some of the above uses if its temperature can be kept below $177^{\circ} \mathrm{C}\left(350^{\circ} \mathrm{F}\right)$.

The existing water cooling system could be modified to keep the SERF vessel below $177^{\circ} \mathrm{C}\left(350^{\circ} \mathrm{F}\right)$; however, appropriate assurances should be made to prevent water from penetrating the primary reactor containment of the HFFFR and flooding the core. If such precautions are not taken, criticality consequences could occur.

The water cooling system might be modified to cool not only the old reactor vessel but the new one as well. A thorough thermal analysis of both vessels should be carried out with a view to reducing the heat transfer between them. The water flowing from the SERF vessel would move counter to the heat flow and iuuld luncelvably serve as an emergency cooling circuit in case the helium loop breaks down. Once again it must be emphasized that this will be possible only if water can be kept out of the gas-cooled core. 


\section{APPENDIX G}

HFFPR System Layout in the SERF Building

The overall structure of the SERF building is illustrated in Figure G-1. Floor plans for this facility are given in Figures G-2, G-3, and G-4.

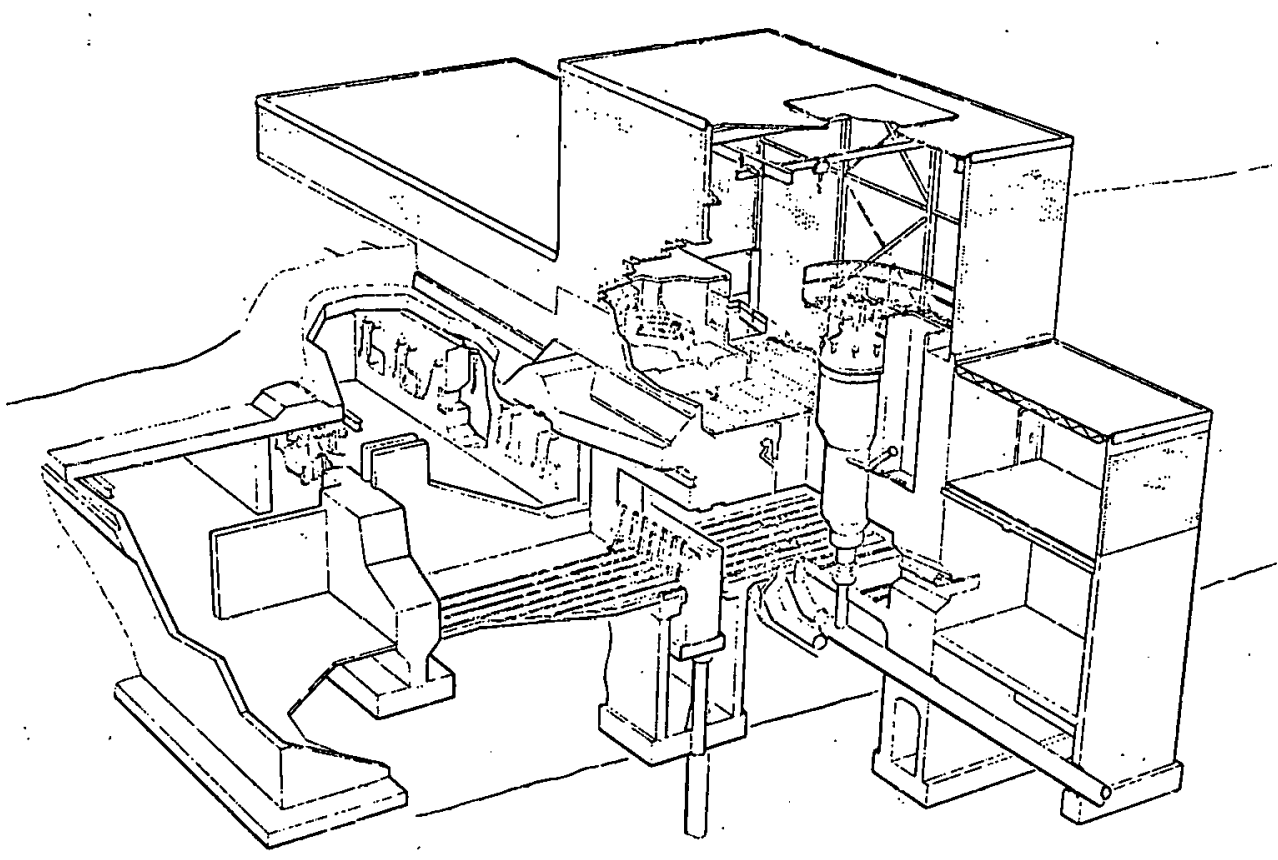

Figure G-1. Sandia Engineering Reactor Facility (SERF)

It is assumed that the helium-to-water heat exchanger will utilize a concentric pipe such as is used in the steam generators at the Peach Bottom HTGR for the helium. For this configuration, only one hole needs to be cut from the lower part of the beam room to the reactor vessel. The helium-to-water heat exchanger should be located in the beam room since this room can provide some shielding against the radioactivity that might be present. This layout is illustrated in Figure G-5. The secondary water heat exchanger may be placed in the pump house together with the two water pumps in the manner illustrated in Figure G-6. 


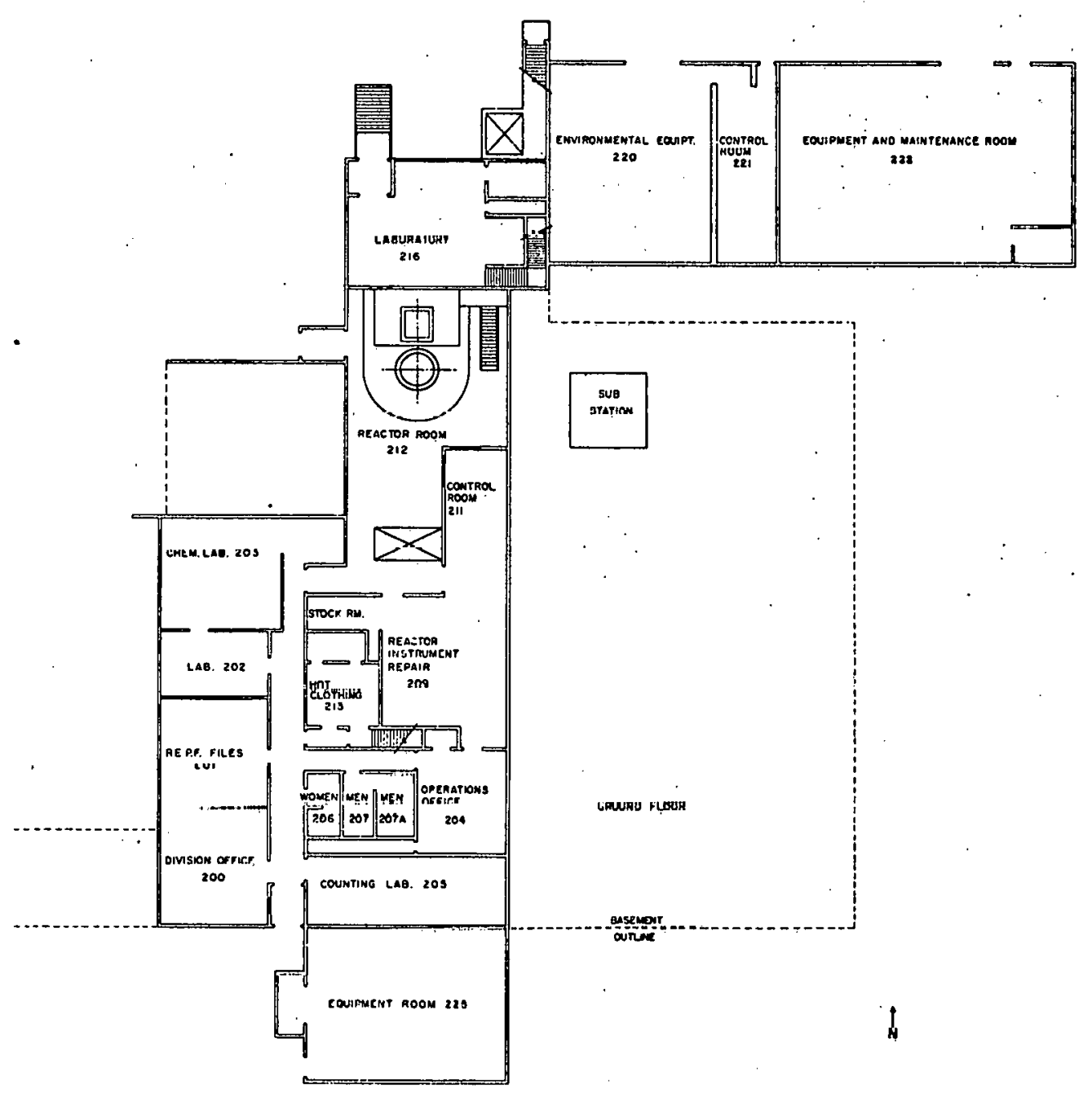

Figure G-2. Ground Floor Plan 


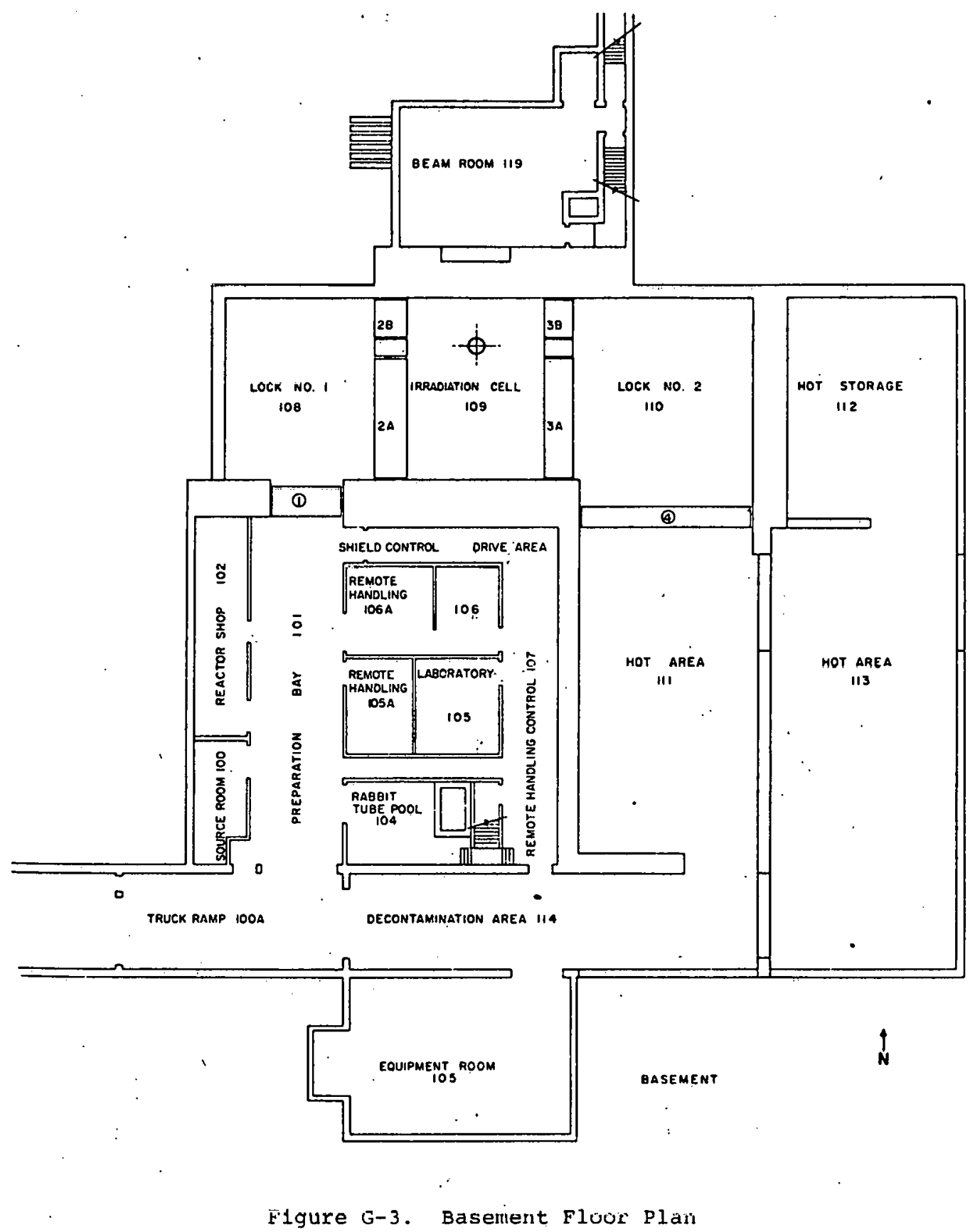




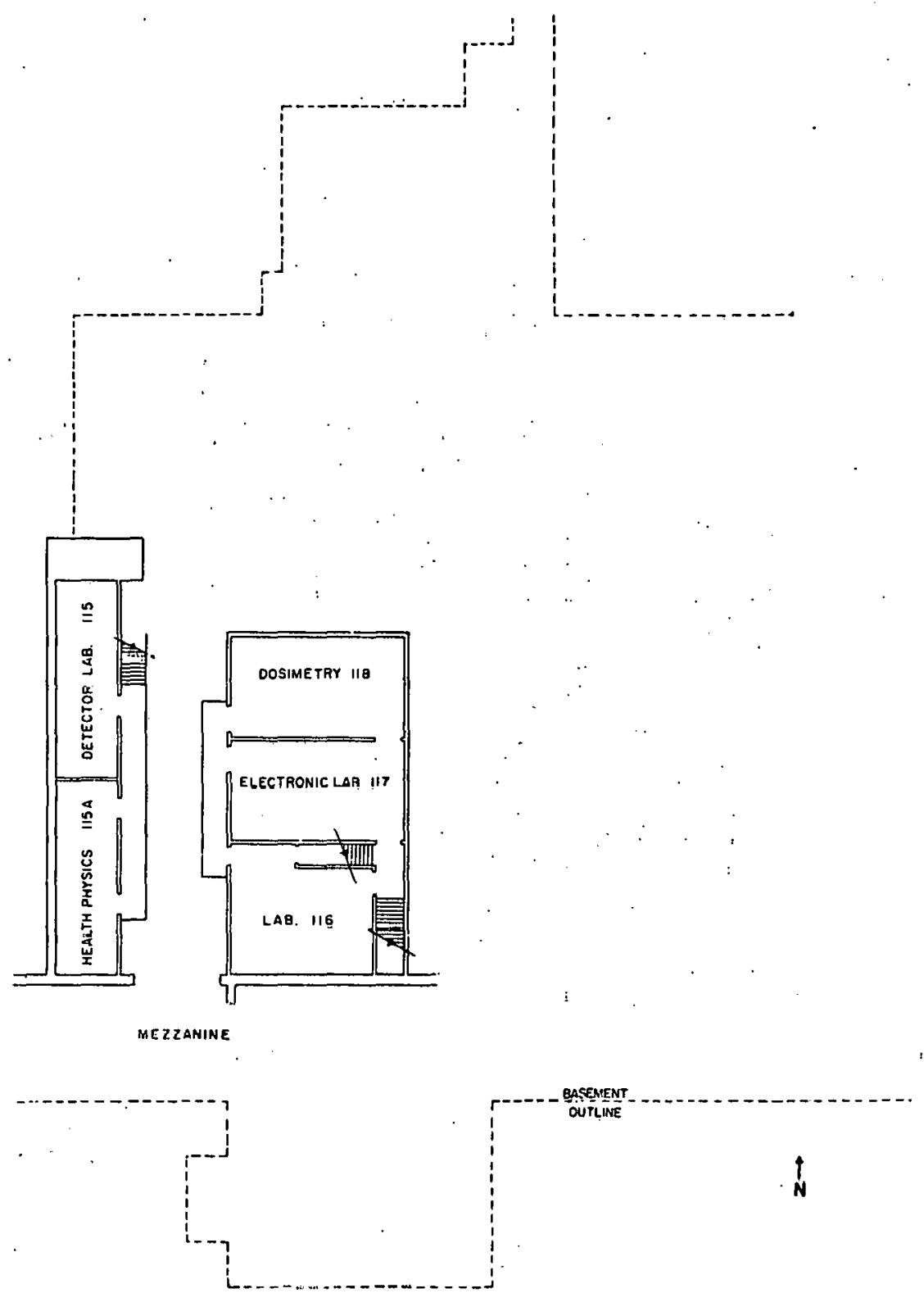

Figure G-4. Mezzanine F́loor Plan 


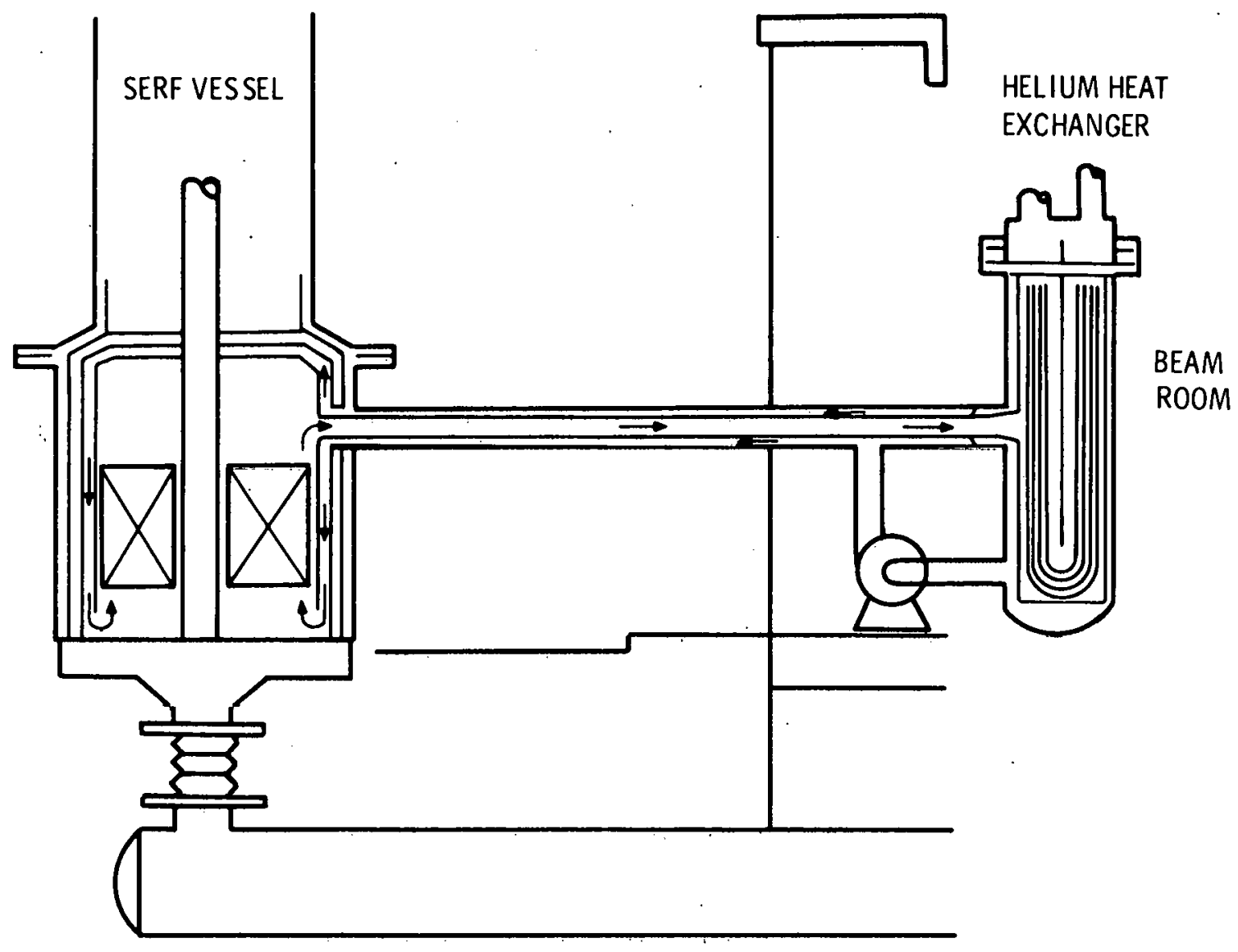

Figure G-5. HFFPR Helium Cooling Circuit

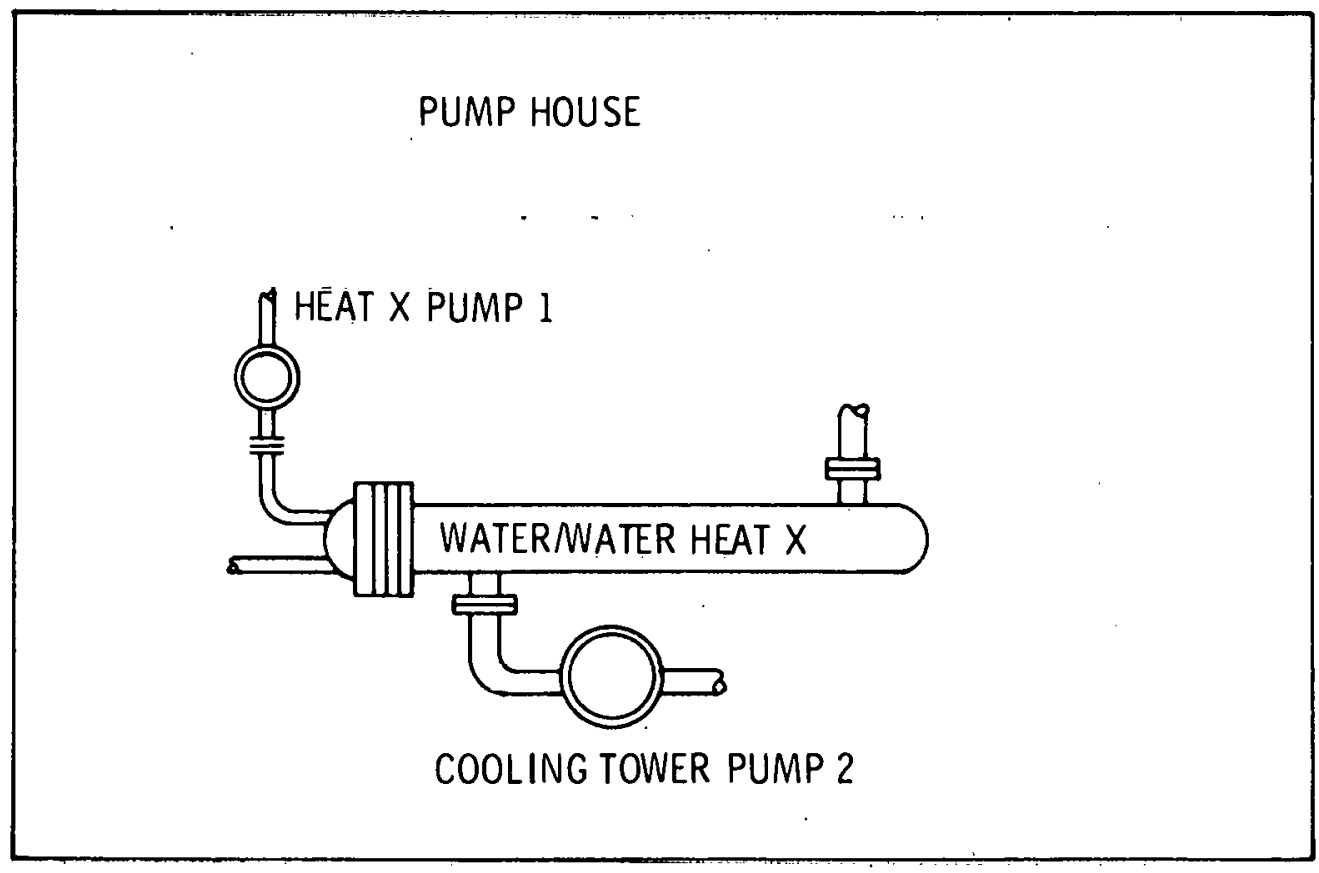

Figure G-6. Location of Water Heat Exchanger 
The helium purification system should be built as a modular unit and be placed in Lock No. 1 (see Figure G-7). A gas-tight liner complete with a gastight door should be constructed in Lock No. 1 . In addition, Lock No. I should be operated at a negative pressure in relation to other adjacent rooms in the building. These safety precautions are necessary to prevent the escape of any gas which could be slightly radioactive. The price of the helium purification system is estimated to be approximately $\$ 250,000$.

LOCK I

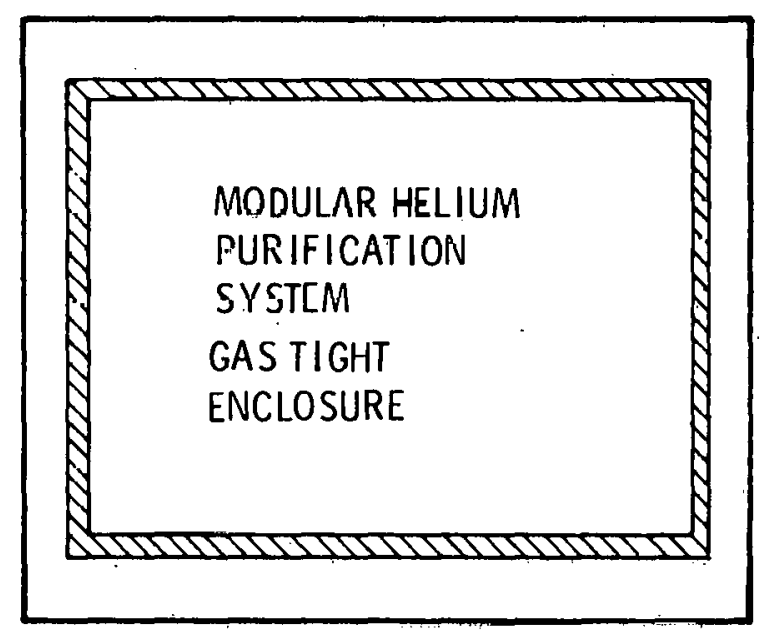

Figure G-7. Location of Helium Purification System 
Some Analytical Conclusions and a Discussion of System Cost

Figure 1 (page 8) summarizes the nominal operating condition of the proposed HFFPR cooling system. The input and output temperatures chosen for the hot side of the helium heat exchanger were based on computer calculations obtained with a simple linear model of the cooling systems devised for this report.

In Figure $\mathrm{H}-\mathrm{I}$, a graph plotted from computer output shows the relationship between heat exchanger volume versus temperature difference across the heat exchanger. The high temperature on the hot side was held constant while the low temperature was dropped as indicated. The helium velocity in the heat exchanger did not vary. This indicates that in this case the heat exchanger increases in volume as temperature across the heat exchanger increases.

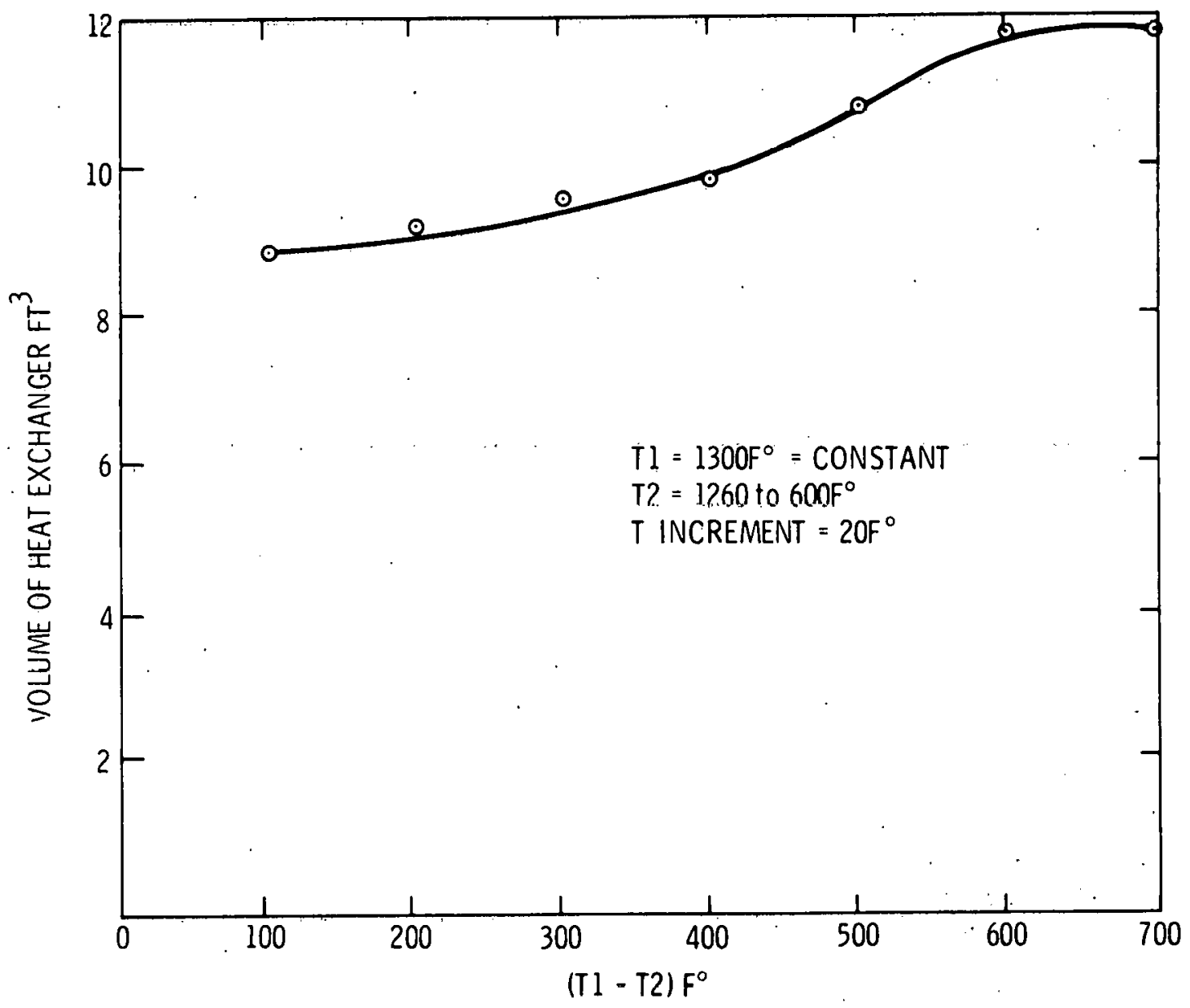

Figure H-1. Heat Exchanger Volume Variation with Temperature Increment 
In the graph plotted in Figure $\mathrm{H}-2$, the low temperature on the high side is kept constant, while the high temperature on the high side increases as shown. In this instance, the heat exchanger volume decreases as the temperature drop across the heat exchanger increases.

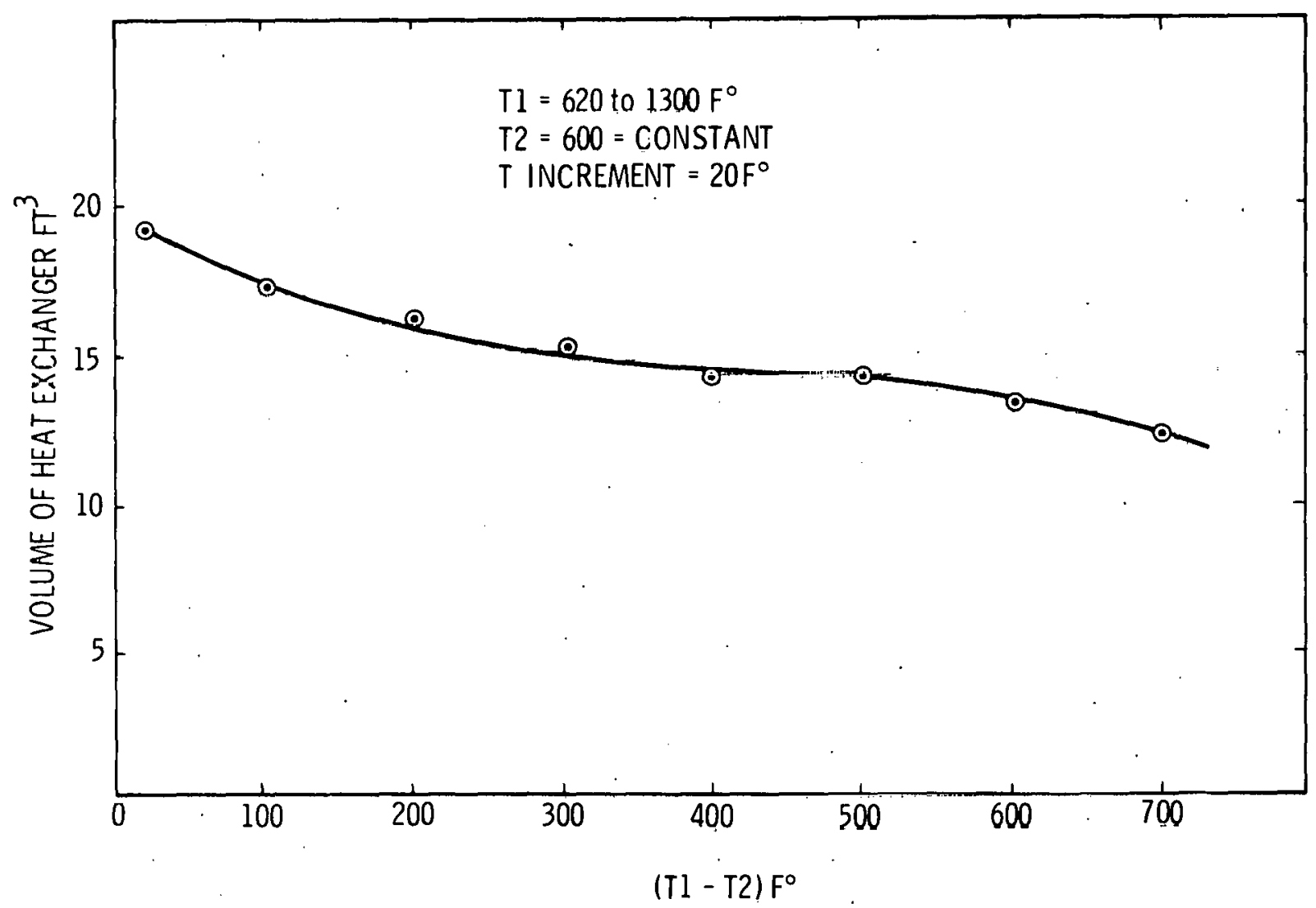

Figure H-2. Heat Exchanger Volume Variation with Temperature Increment

Figure $\mathrm{H}-3$ shows that in both of the preceding cases the helium flow rate decreases as the temperature drop across the heat exchanqer increases. Since the helium pump is the most expensive item, the temperature difference which gives the lowest helium flow rate and which can be handled by the materials involved represents the most economical temperature drop for the system. The reactor output temperature of $649^{\circ} \mathrm{C}\left(1200^{\circ} \mathrm{F}\right)$ can be easily handled by the materials which have been chosen, and the $260^{\circ} \mathrm{C}\left(500^{\circ} \mathrm{F}\right)$ inlet temperature glves enough temperature drop to assure a helium flow rate that can be handled by readily available helium pumps.

Table H-I summarizes the estimated prices of all the major components in the cooling system. Hence, the total cost of the overall cooling system can be estimated to be approximately $\$ 1.5$ million. In addition, it may be necessary to purchase a standby helium pump which can be brought online in case the main pump fails. If so, the cost of the cooling system will increase to approximately $\$ 2$ million. 


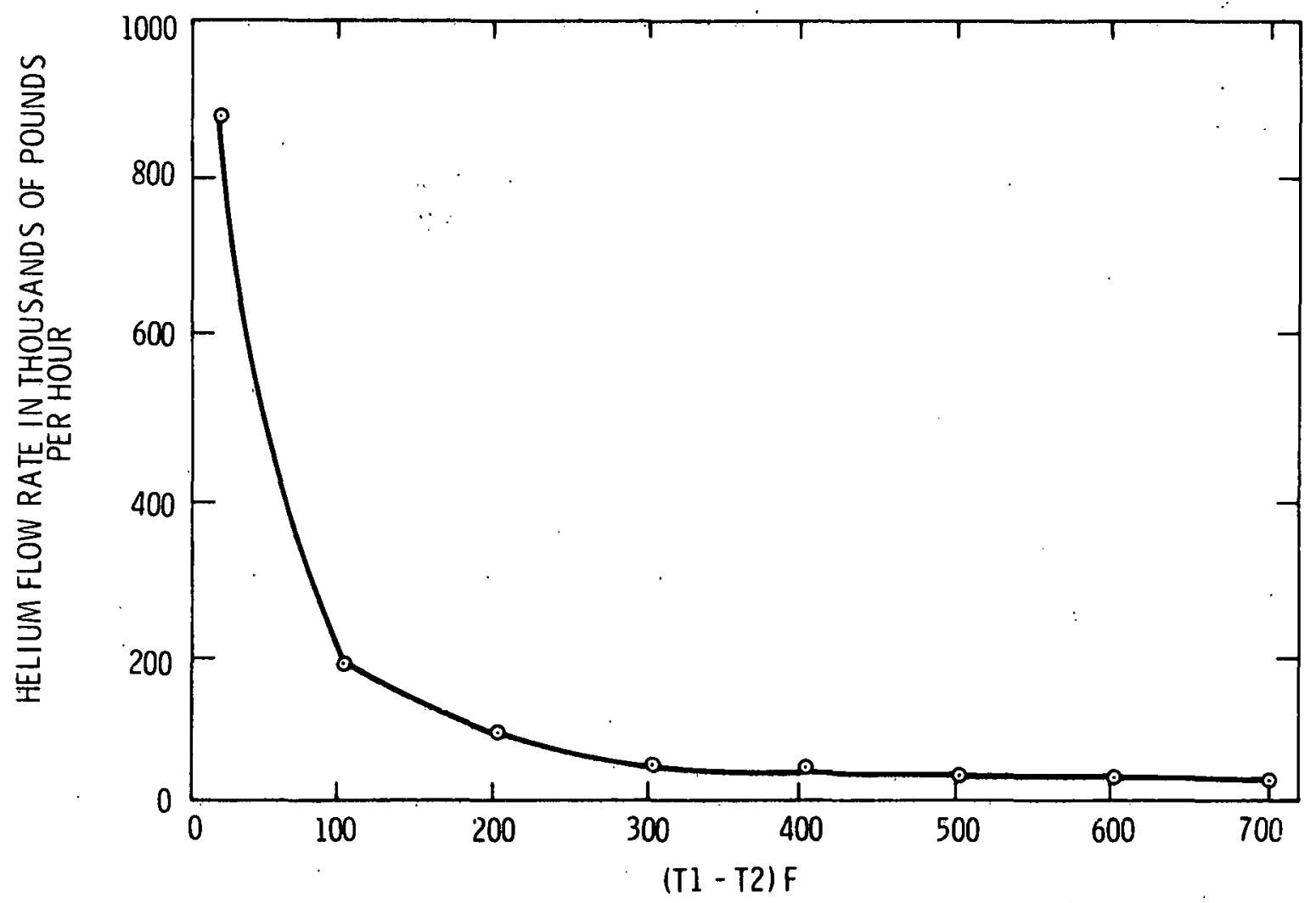

Figure H-3. Helium Flow Rate with Temperature Increment

TABLE H-I

Estimated Prices of Major Components

Helium-heat exchanger

water-heat exchanger

Helium pump

Helium pump controller

water pump 1

Water pump 2

Helium purification system

Total

$$
\begin{array}{r}
\$ 100,000 \\
25,000 \\
450,000 \\
75,000 \\
1,700 \\
3,000 \\
250,000 \\
\$ 904,700
\end{array}
$$

It is possible that a nominal 12-inch concentric pipe which has cold helium on the outside and hot helium on the inside will be sufficient for thc helium circuit. A 5-inch pipe will carry the water between the heat exchanger and a 6-inch pipe should be adequate to transport the water to the cooling tower. 
It appears that all the necessary equipment needed to construct the cooling system for the gas-cooled HFFPR can be placed in the old SERF building and its proposed additions. The sizes of the heat exchangers should not be greater than 0.9 metre (3 feet) in diameter and 3 metres (10 feet) in length. The pumps will be very small and the helium purification module will fit into a room the size of Lock No. 1 which is 9.1 by 7.9 by 3.4 metres ( 30 by 26 by 11 feet) in size. 


\section{References}

1. W. G. Schuetzenduebel, "High-Temperature Gas-Cooled Reactor Steam Generator Design," Nuclear Technology, 28, (March 1976), 315.

2. "Prototype High-Temperature Gas-Cooled Reactor and Development Program," Progress Reports: GA-1640, GA-1774, GA-1982, GA-1878, GA-2204, and GA-1235, General Atomic, 1960-61.

3. "Application of Philadelphia Electric Company for Construction Permit and Class 104 License," NP-9115, Peach Bottom Atomic Power Station, Part A, Philadelphia Electric Co., 1960.

4. G. E. Lockett and R. A. Huddle, "The Dragon Reactor," Nuclear Power, (February 1960), 112.

5. P. Marion, ed., "Report for Period July 1, 1960 to December 31, 1960. Project Dragon," Atomic Energy Establishment, Winfrith, England, June 1961.

6. F. C. Wood, "Coolant Processing in the Dragon Project," Atomic Energy Establishment, Winfrith, England, July 1962.

7. "Ultra.High Temperature Reactor Experiment (UHTREX) Facility Description and Safety Analysis Report," LA-3556 (Revised), U.S. Atomic Energy Commission, Prepared by K-Division, work done by CMB, GMX, H, J, K, T, and W Divisions and the Engineering Department, September 1966.

8. P. Fortescue, "Gas-Cooled Fast Breeder Reactor Development-Design of a 330-MW Demonstration Power Plant," Proceedings of the American Power Conference, 31, (1969), 116 .

9. G. B. Melese-d'Hospital and J. B. Dee, "Gas-Cooled Fast Breeder Reactor Designs," ASME paper: CONF-710315 15, 71-ME-2, Nuclear Engineering Conference, Palo Alto, California, March 7-10, 1971.

10. P. Fortescue and G. M. Schultz, "A 1000-MWe Gas-Cooled Fast Breeder Reactor," Proceedings of the American Power Conference, 29, (1967), 178.

11. Heat Exchangers, Manual No. 700-A of the Patterson-Kelley Co., Inc., East stroudsurg, Pennsylvania.

12. J. A. Bond, E. C. Duderstadt, K. G. Frank, and B. L. Moor, "Design of a Helium-Heated Duplex-Tube Steam-Methane Reformer," General Electric Company Energy systems and l'echnology uivision, Es'Tu-76-06, May $19 \%$.

13. E. Popov, Introduction to Mechanics of Solids, (New Jersey: Prentice-Hall, $1968), 349$.

14. A. P. Fraas, Heat Exchanger Design, (New York: John Wiley \& Sons, 1965).

15. W. McAdams, Heat Transmission (New York: McGraw-Hill, 1954).

16. H. A. Kuljian, Nuclean Power plant Design, (Lundun: A. S. Barnes and Company, 1970), 75 .

1\%. F. Kreith, Principles of Heat Transfer, 3rd ed., (New York: Dun-Donnelly Publisher, 1973).

18. Mechanical Technology Incorporated, 968 Albany-Shaker Road, Latham, New York (Private Communication).

19. Aurora Pump, A Unit of General Signal, 800 Airport Road, North Aurora, Illinois 60542, (Private Communication). 
20. Marley Corporate Offices, 5800 Foxridge Drive, Mission, Kansas 66202 (James \& Cooke, Inc., Albuquerque representatives).

21. A. Hasenkamp, "Final Hazards Summary for the Sandia Engineering Reactor Facility (SERF)," SC-4522(RR), Sandia Laboratories, Albuquerque, New Mexico, September 1961 .

22. E. T. W. Tsui, Stresses in Shells of Revolution, Pacific Coast Publishers, Menlo Park, California, 1968 . 
DISTRIBUTION :

U.S. Nuclear Regulatory Commission (3) Office of Nuclear Regulatory Research Division of Reactor Safety Research washington, DC 20555

Attn: C. N. Kelber

M. Silberberg

R. W. Wright

R. L. Brehm (2)

College of Engineering

The University of Arizona

Tucson, AZ

Los Alamos Scientific Laboratory

P.O. Box 1663

Los Alamos, NM 87545

Attn: F. P. Schilling, WX-4, MS 985

T. J. Merson, WX-4, MS 985

R. F. Warner, MS 842

1136

1213

H. C. Walling

1760

2324

3642

3643

3643

4400

4410

4415

H. C. Monteith (10)

J. A. Andersen

J. P. Abbin

E. E. Rush

J. T. Hall

C. R. Mills

A. W. Snyder

D. J. McCloskey

D. A. Dahlgren

4420 J. V. Walker (2)

4420 A P. S. Pickard

4423 B. Rosenstroch

4450 J. A. Reuscher

4452 L. D. Posey

4452 J. S. Philbin

4452 W. E. Nelson (SAI)

4550 W. A. Von Riesemann

5521 R. K. Thomas

5832 C. H. Maak

5832 H. J. Rack

8266 E. A. Aas

3141 T. L. Werner (5)

3151 W. L. Garner (3)

For: DOE/TIC (Unlimited Release)

DOE/TIC (25)

(R. P. Campbell, 3172-3) 